This is the final peer-reviewed accepted manuscript of:

Polonia, A; Nelson, C. H.; Romano, S.; VAIANI, STEFANO CLAUDIO; Colizza, E.; GASPAROTTO, GIORGIO;

Gasperini, L.: A depositional model for seismo-turbidites in confined basins based on lonian Sea deposits.

Marine Geology. 384. 0025-3227. DOI: 10.1016/j.margeo.2016.05.010

The final published version is available online at:

http://dx.doi.org/10.1016/.j.margeo.2016.05.010

Rights / License:

The terms and conditions for the reuse of this version of the manuscript are specified in the publishing policy. For all terms of use and more information see the publisher's website.

This item was downloaded from IRIS Università di Bologna (https://cris.unibo.it/)

When citing, please refer to the published version. 


\title{
A depositional model for seismo-turbidites in confined basins based on Ionian Sea deposits
}

\author{
A. Polonia ${ }^{\text {a, } *}$, C.H. Nelson ${ }^{\text {b }}$, S. Romano ${ }^{\text {a }}$, S.C. Vaiani ${ }^{\text {c }}$, E. Colizza ${ }^{\text {d }}$, G. Gasparotto ${ }^{\text {c }}$, L. Gasperini \\ a \\ a Institute of Marine Science CNR ISMAR-Bo, Via Gobetti, 101, 40129 Bologna, Italy \\ b CSIC, University of Granada, Spain \\ c Dipartimento di Scienze Biologiche, Geologiche e Ambientali, University of Bologna, Italy \\ d Dip. di Matematica e Geoscienze, Universita' degli Studi di Trieste, Italy
}

\begin{abstract}
A B S T R A C T
This study investigates Ionian Sea seismo turbidite (ST) deposits that we interpret to be triggered by major historic earthquakes and tsunamis in the Calabrian Arc. ST beds can be correlated with the AD $1908 \mathrm{Mw} 7.24$ Messina, AD 1693 Mw 7.41 Catania, and AD 1169 Mw 6.6 Eastern Sicily earthquakes while two previously unknown turbidites might have been generated by the AD 1818 Mw 6.23 Catania and AD $1542 \mathrm{Mw} 6.77$ Siracusa earthquakes. Textural, micropaleontological, geochemical and mineralogical signatures of STs reveal cyclic patterns of STa, STb, STc and STd sedimentary units for each earthquake with an associated tsunami. The STa unit contains multiple ST stacks with different mineralogy, geochemistry foraminiferal assemblages and sedimentary structures that are deposited from synchronous multiple slope failures and turbidity currents. The STb homogenite graded mud unit overlying the STa unit is deposited by the waning flows of the multiple turbidity currents that are trapped in the Ionian Sea confined basin. The STc laminated and marine sourced unit results from seiching of the confined water mass that appears to be generated by earthquake ruptures combined with tsunami waves. The STd unit is a tsunamite cap deposited by the slow settling suspension cloud created by tsunami wave backwash erosion of the shoreline and continental shelf. This tsunami process interpretation is based on the textural gradation of the upper unit and a more continental source of the tsunamite cap which includes $\mathrm{C} / \mathrm{N}>10$ and the presence of inner shelf foraminifera with a lack of abyssal species. This interpretation is in agreement with the lack of a tsunamite cap for the turbidite likely linked to the AD 1542 historic earthquake that is not associated with a tsunami. The new sedimentologic criteria identifies the final seiche and tsunamite cap deposits of STs and provides a model that can now be tested in other locations to better understand the different depositional processes of seismo turbidites in confined basins.
\end{abstract}

\section{Introduction}

Earthquake geology in underwater environments is a widely applied method used to reconstruct paleoseismicity back to prehistorical times in many different active tectonic settings, both in lake (Strasser et al., 2013; Moernaut et al., 2014; Howarth et al., 2014) and marine basin floors (Patton et al., 2015 and references therein).

The abyssal plain in the Ionian Sea is a good site for turbidite paleoseismological studies because river floods and/or prodeltaic failures do not affect this area (Fig. 1). Also there are detailed historical earthquake catalogues, that can be linked to the specific turbidite units in the uppermost part of the sedimentary sequence.

\footnotetext{
* Corresponding author.

E-mail address: alina.polonia@ismar.cnr.it (A. Polonia).
}

The term "seismo turbidite", here indicated as "ST", was first introduced by Mutti et al. (1984) to describe "repetitive turbidites deposited in highly mobile basins" with particular reference to the Apennines. In the same year, Kastens (1984) introduced the term "marine paleoseismology" when studying turbidite and debris flow deposits in the outermost Calabrian Arc accretionary complex and searching for distinctive earthquake emplaced sedimentary structures. In her study, the Ionian deep sea was described as an ideal site for testing this approach, because of the long interval of deposition with little influence from river inputs. In addition, the abyssal plain is located between two active subduction systems, the mega thrust sources of the Hellenic Arc, and the closer Calabrian Arc, where tectonic activity and resulting earthquakes are the "normal" catastrophic events that deposit sediment in the $4000 \mathrm{~m}$ deep basin (Polonia et al., 2013a, 2013b, 2016a; Köng et al., 2016). 


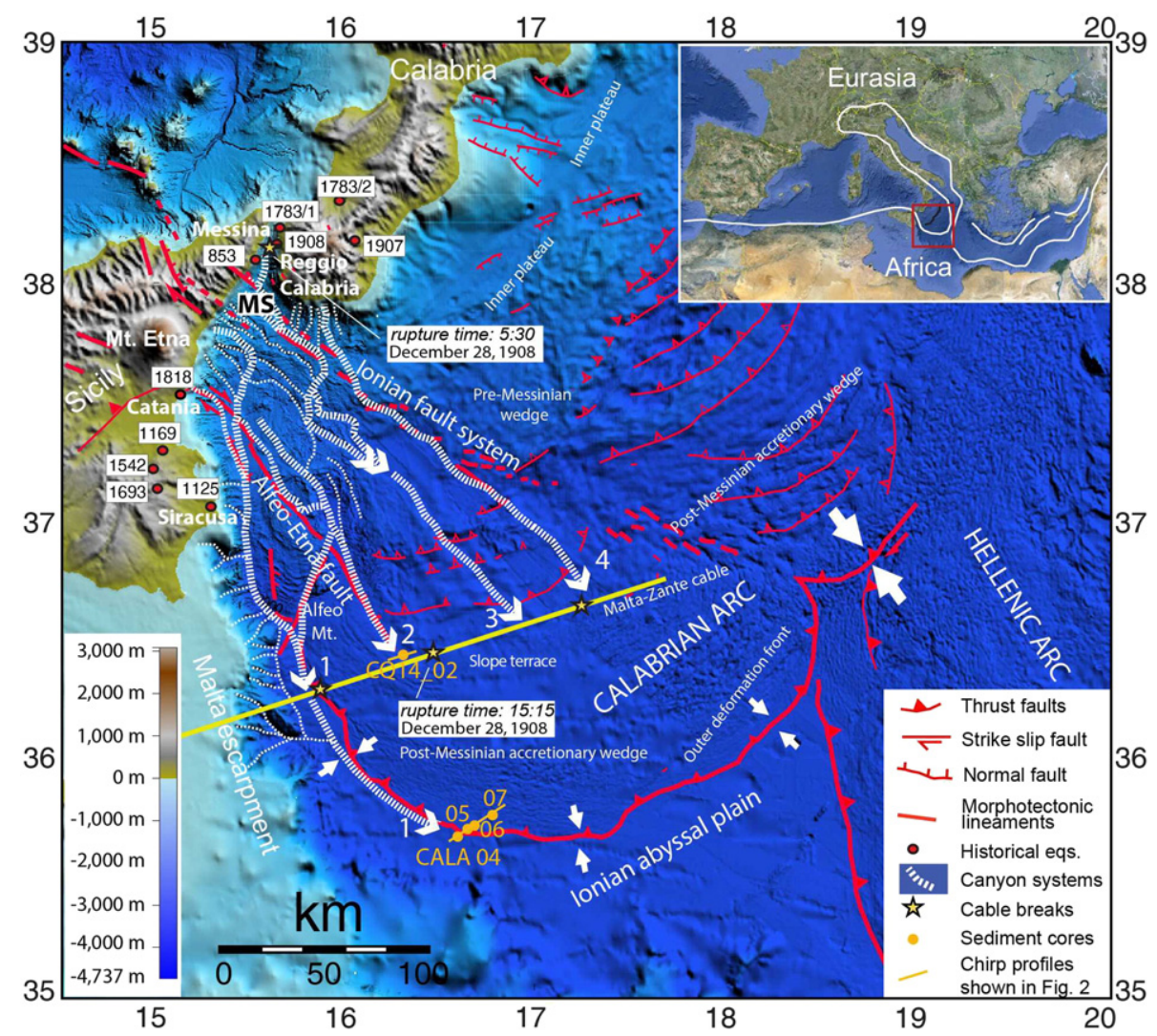

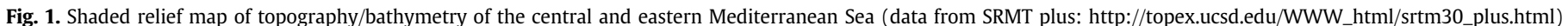

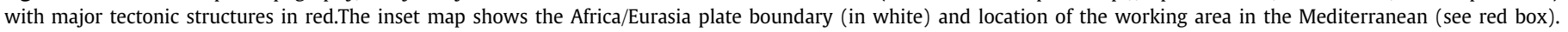

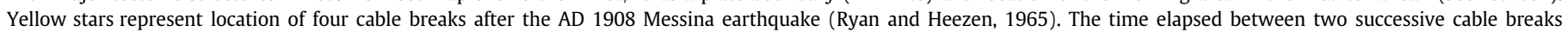

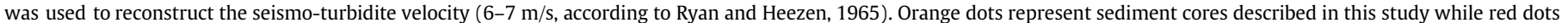

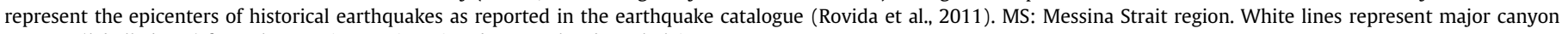
systems (labelled 1-4) from the Messina Strait region down to the abyssal plain.

Modified from Polonia et al. (2011, 2016b).

Radiometric and short lived radionuclide ages are available for the most recent turbidite sequences, that were sampled by gravity coring in the Ionian Sea. These ages have been used to generate a chronology

Table 1

Major historical earthquakes in the study area that have Mw $>5.8$ (Rovida et al., 2011). In grey earthquakes that triggered the deposition of a seismo-turbidites in the analyzed cores. TSUN: earthquakes associated with tsunamis (Tinti et al., 2004).

\begin{tabular}{|c|c|c|c|c|c|}
\hline Date & & Location & Lat $\mathrm{N}$ & Lon $\mathrm{E}$ & Mw \\
\hline 19081228 & TSUN & Southern Calabria & 38.15 & 15.68 & 7.24 \\
\hline 19071023 & TSUN & Southern Calabria & 38.13 & 16.02 & 5.87 \\
\hline 18180220 & TSUN & Catania & 37.60 & 15.14 & 6.23 \\
\hline $1783 / 10206$ & TSUN & Messina region & 38.22 & 15.63 & 5.94 \\
\hline $1783 / 20205$ & TSUN & Southern Calabria & 38.30 & 15.97 & 7.02 \\
\hline $1693 / 20111$ & TSUN & Eastern Sicily & 37.14 & 15.01 & 7.41 \\
\hline $1693 / 10109$ & TSUN & Val di Noto & 37.14 & 15.03 & 6.21 \\
\hline 15421210 & & Siracusa & 37.21 & 14.94 & 6.77 \\
\hline 11690204 & TSUN & Eastern Sicily & 37.32 & 15.03 & 6.41 \\
\hline 11250607 & & Siracusa & 37.08 & 15.28 & 5.78 \\
\hline
\end{tabular}

of turbidite sedimentation associated with earthquakes along the Africa/Eurasia convergent margin (Polonia et al., 2013a, 2013b, $2015,2016 a)$. The chronology provided by high resolution radiocarbon ages of pelagic sediment layers and chronostratigraphic ages based on sedi mentation rate, has been correlated with the historical earthquake cat alogue. This indicates a match between turbidite emplacement time and the major historic earthquakes in AD 1908, 1693 and 1169 (Table 1). We summarize methods and main results of the previous and present age studies in Supplementary SM1.

Although the AD 1908, 1693 and 1169 earthquakes have been correlated with STs, some important issues about turbidite generation in the Io nian Sea remain to be resolved. The three above historic earthquakes which triggered turbidity currents are all associated with tsunamis (Tinti et al., 2004), although it is not clear how the tsunami wave contributed to sediment remobilization and whether the tsunamis were generated by seafloor ruptures on the fault planes, or by submarine slope failures triggered by seismic shaking. For example, the huge tsunami of the most recent and best known event in the region, the AD 1908 Messina earth quake, caused about $11 \mathrm{~m}$ of run up and tremendous devastation on the coasts of Sicily and Calabria, with tens of thousands of lives lost (Omori, 1909; Platania, 1909; Baratta, 1910; Tinti et al., 2004). However, if we consider the proposed fault sources for earthquakes, only $1 \mathrm{~m}$ of such run up could be explained by fault rupture (Okal and Synolakis, 2004); the effect of submarine landslides need to be invoked to account for the AD 1908 high tsunami run up (Tappin, 2008; Billi et al., 2009; Favalli et al., 2009; Ridente et al., 2014). The detailed analysis of the AD 1908 ST layer in this paper provides insights on the ST generation, sediment sources and turbidity current pathways, and information on the general issue of submarine landslide vs. fault rupture in generating tsunamis. 
The 11 January AD 1693, Mw 7.41 Catania earthquake, the strongest recorded in Italy, is part of a sequence of earthquakes and triggered the deposition of a thick ST in the abyssal plain. However, the source(s) of the AD 1693 earthquake(s) is/are still highly debated (see Section 3 and Polonia et al., 2012, 2013a for a review). The detailed analysis of the correlative ST may provide useful information about these sources and relative contribution from each individual earthquake of the AD 1693 seismic sequence.

Another key issue in ST studies is evaluating the contribution of tsunami wave generation related to the deposition of STs. The catastrophic 2004 Sumatra and 2011 Tohoku earthquakes triggered devastating tsunamis whose effects have been studied using the state of the art methods applied to earthquake geology (Arai et al., 2013; Ikehara et al., 2014; Patton et al., 2013, 2015; Sumner et al., 2013; Goldfinger et al., 2014). Associated STs have been identified, some of which could have been deposited by tsunami backwash (Arai et al., 2013).

Only two deep sea "tsunamite" STs have been proposed to date. One is the thick (up to $25 \mathrm{~m}$ ) Homogenite/Augias turbidite in the Ionian Sea
(Kastens and Cita, 1981; Polonia et al., 2013a, 2016a), and the second are some centimeter thick deposits triggered by the 2011 Tohoku Oki earthquake and tsunamis (Arai et al., 2013; Ikehara et al., 2014; McHugh et al., 2016). However, no detailed studies were performed on these deposits to unravel similarities and/or differences between tsunamis triggered turbidites and turbidites triggered by direct earthquake shaking (Nelson et al., 2012; Gutiérrez Pastor et al., 2013).

In this study we use three gravity cores (CALA 04, CALA 05 and CQ14_02), selected among a larger dataset, for a multi proxy study to characterize each ST unit. Two additional cores (CALA 06 and CALA 07) are used for turbidite correlation. Our multi proxy approach helps to unravel the relative contribution of seismic shaking (sediment failures, MTDs, turbidity currents e.g. Van Daele et al., 2014) and tsunami wave processes (overwash surges, backwash flows, turbidity currents, basin seiching e.g. Shiki and Cita, 2008; Pattiaratchi and Wijeratne, 2009; Hilbe and Anselmetti, 2015) that deposit abyssal plain STs and provide criteria to decipher processes for STs elsewhere.
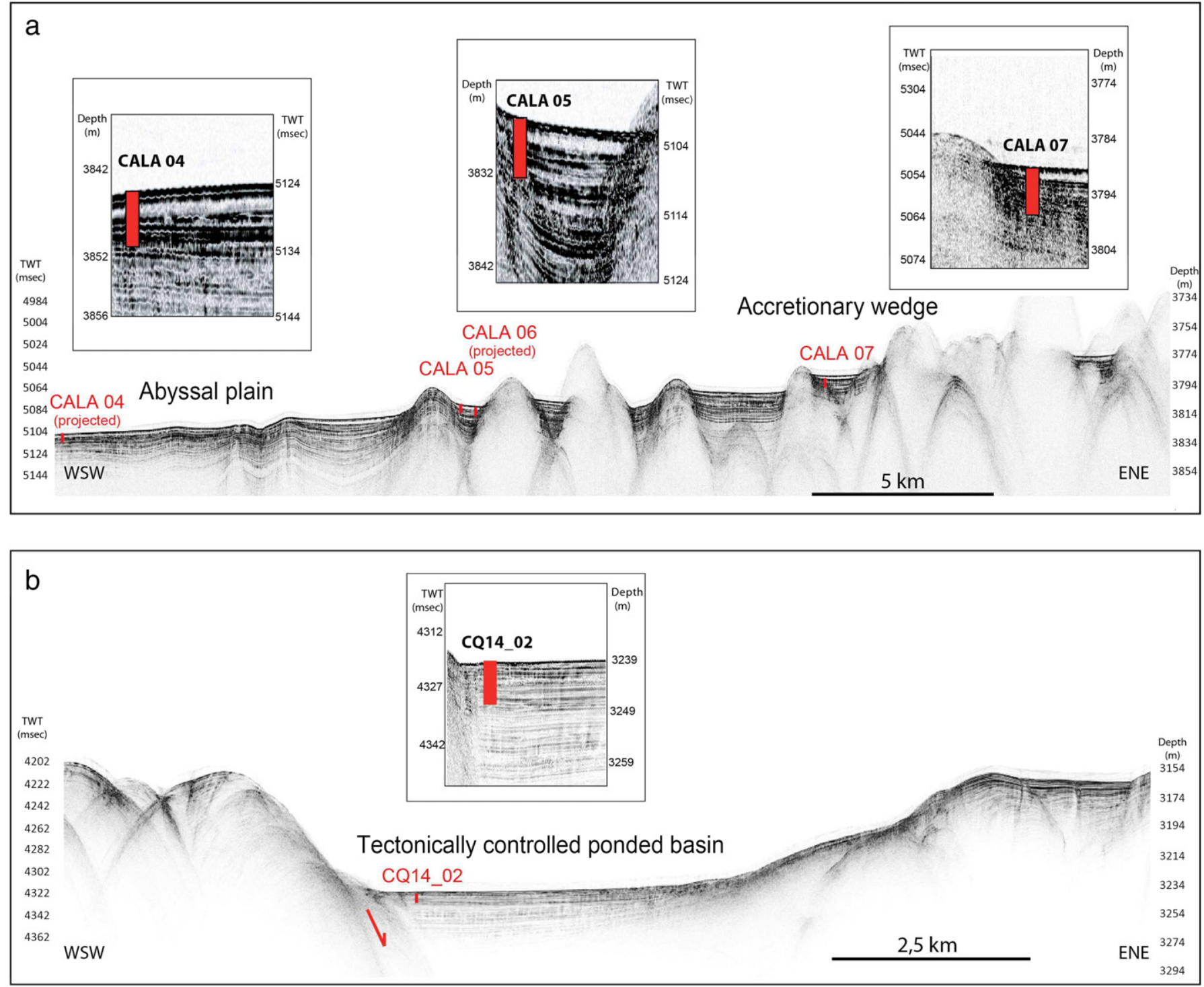

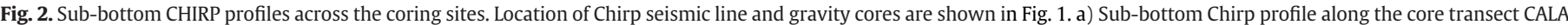

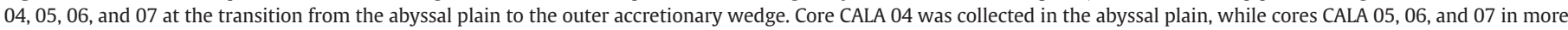

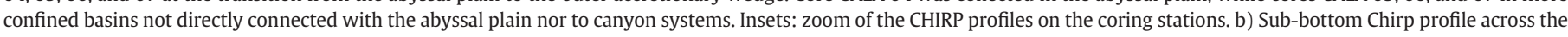
tectonically controlled ponded closed basin at a canyon mouth where CQ14_02 was collected. Gravity cores are represented in red. 


\section{Geological setting}

In the western Ionian Sea margin the crust of the African plate is being subducted beneath Calabria (Fig. 1). Plate convergence is accommodated along the outer deformation front (i.e., the plate boundary) that marks the transition from the $4000 \mathrm{~m}$ deep abyssal plain and the accretionary wedge that constitutes the continental slope. The accre tionary wedge consists of: i) the frontal wedge made up of evaporites, whose deformation produces confined sedimentary basins; and ii) the inner wedge, with steeper slopes and submarine canyons which feed wider perched basins and slope terraces (Figs. 1 and 2) (Polonia et al., 2011). High uplift rates (up to $2 \mathrm{~mm} / \mathrm{year}$ ) of the coastal mountains are the shallow response to mantle upwelling at edges of the narrow and retreating slab (Faccenna et al., 2011), and result in enhanced sed iment discharge onto the continental shelves. A number of active defor mation belts, parallel and orthogonal to the trench, control the physiography of the margin and the sediment dispersal (Fig. 1).

Bathymetric maps and previous studies on active faults in the Ionian region show a strong interplay between structural development, location and continuity of canyon systems (Fig. 1). Three main tectonic features, which segment the continental margin (i.e. the Malta escarpment, the Alfeo Etna fault system and the Ionian fault), control the paths of major canyons (Polonia et al., 2016b). The Alfeo Etna fault, a lithospher ic transtensive fault, marks the boundary between two different canyon systems. To the west of the fault, canyons from the Mt. Etna region (N. 1 in Fig. 1) connect with the steep and short canyons crossing the Malta escarpment and continue at its base before reaching the abyssal plain. Some of the canyons from the Messina Strait region connect with the western canyons located north of the Alfeo seamount (Fig. 1). To the east of the Alfeo Etna fault a number of anastomosing canyons from the Messina Strait and southern Calabria region reach the slope terrace located at about $3000 \mathrm{~m}$ of water depth (canyon systems N. 2, 3, 4 in Fig. 1). Southeast of the slope terrace, the canyon systems do not continue due to the low topographic gradient of the evaporite bearing frontal wedge (taper angle $<2^{\circ}$ ) and the presence of a rough topography made up of structural highs and depressions (Fig. 1).

Uplifting coastal mountains in Calabria and northeastern Sicily com bined with the recent occurrence of Mediterranean tropical like cy clones (Miglietta et al., 2011) make the Ionian Sea prone to river floods and hyperpycnal flows (Casalbore et al., 2011) that need to be taken into account as potential triggering mechanisms for turbidity cur rent generation. This issue becomes significant given the close proxim ity of Calabrian canyon heads to the shoreline during highstand conditions of sea level.

The purpose of this paper is to carefully examine the sedimentologic characteristics of the Ionian Sea turbidites that are correlated with his toric earthquakes, so that we can define the sedimentary processes that are related to the earthquake generation and help to provide criteria that distinguish seismo turbidites from turbidites generated by numerous other processes such as river flood, hyperpycnal flows, storms, and random slope failures.

\section{Seismicity}

Eastern Sicily and southern Calabria bear a historical record of de structive earthquakes often associated with tsunamis (Rovida et al., 2011; Tinti et al., 2004). In the study area, historical earthquakes with $\mathrm{Mw}>5.8$ for the last 1000 years include the AD 1908, 1907, 1818, 1783, 1693, 1542, 1169 and 1125 earthquakes (Table 1). Despite the availability of a detailed earthquake catalogue (Rovida et al., 2011), the source parameters of most earthquakes are still debated, and con troversial interpretations exist especially for the earthquakes that may have been generated offshore, or along faults that extend into the sub merged portion of the Calabrian Arc subduction system.

On 28 December 1908, a catastrophic earthquake (Mw 7.24) resulted in the almost complete destruction of Messina and Reggio Calabria.
Within minutes after the earthquake, a tsunami with a maximum observed run up of about $11 \mathrm{~m}$ hit the coasts of Calabria and Sicily and caused 60,000 deaths (Boschi et al., 2000). Although it is generally agreed that the earthquake was the result of normal faulting in the Messina Strait area, there are still uncertainties about specific location and throw of the causative fault (Pino et al., 2009 and references therein).

The AD 1693 earthquake hit eastern Sicily, with a strong seismic sequence starting on 9 January ( $\mathrm{Mw}=6.21$ ), and a main shock on 11 January, with an estimated magnitude of Mw 7.41 (Rovida et al., 2011). This is the strongest earthquake recorded in the study area, and caused over 60,000 deaths in eastern Sicily (Tonini et al., 2011). However, the identification of a possible causative fault plane remains highly uncertain.

Very little information exists for the 4 February 1169 (Mw 6.6) earthquake, which did strike Eastern Sicily. The earthquake destroyed Catania, although it is not possible to reconstruct in detail the extent of damages in the surrounding areas (Boschi et al., 1997).

Very scarce information is available for the 1542 event, but among earthquakes with $\mathrm{Mw}>5.8$, it is not associated with a reported tsunami. For historical earthquakes, which could have affected the study region, more data is reported in the catalogues (Rovida et al., 2011).

\section{Methods}

Chirp sonar profiles were collected using a TELEDYNE BENTHOS Chirp II system, $37 \mathrm{kHz}$ operating frequency, equipped with hull mounted transducers (15 in total). Chirp sonar data were digitally sam pled and stored in SEG Y files. Quality check and data processing, which included filtering and amplitude equalization, as well as statics and po sitioning correction, was performed onboard using the open ISMAR CNR software SeisPrho (Gasperini and Stanghellini, 2009). Swath ba thymetry was collected using a SIMRAD 710 Multibeam echosounder.

Cores were collected during two cruises, CALAMARE08 (CALA 04, 05) and CALAQUAKE14 (CQ14_02), carried out onboard of R/V Urania in 2008 and 2014, respectively. During CALAMARE08 a 1.2 ton gravity corer was employed, with coring pipes $6 \mathrm{~m}$ long, while during CALAQUAKE14 cores were collected using a 2.3 ton CP20 piston corer, with coring pipes $10 \mathrm{~m}$ long.

Coring sites were selected through analysis of high resolution Chirp sonar data, combined with bathymetric maps, which characterized tec tonic, oceanographic and depositional settings at each core location (Figs. 1 and 2). We selected basin depocenters hundreds of kilometers from the coast to reduce influence by river inputs and sites with reduced sedimentation rates in order to get a longer time span. The cores ana lyzed in this work represent different bathymetric settings (core CALA04: open abyssal plain, core CALA05: confined basin close to the abyssal plain and CQ14_02: slope terrace) (Fig. 1).

The cores sections were analyzed through a multi proxy approach involving sedimentology, physical properties, XRF core scanner, organic matter, micropaleontology and mineralogy.

Grain size for cores CALA 04 and CALA 05 was analyzed with a sampling rate of $1 \mathrm{~cm}$ over the entire studied section. Sediment texture anal yses were performed through the Laser Diffraction Particle Size Analyzer Beckman coulter LS 230, on the $0.042000 \mu \mathrm{m}$ fraction. Core CQ14_02 was subsampled with a sampling rate from 1 to $12 \mathrm{~cm}$ de pending on visual characteristics. Grain size analyses were performed by laser MALVERN Mastersizer 2000 (Hydro 2000S), size range from 0.02 to $2000 \mu \mathrm{m}$ fraction. Results were classified according to Friedman and Sanders (1978) grain size scale.

High resolution Magnetic Susceptibility (MS) was acquired with a core log system (Bartinghton model MS2, $100 \mathrm{~mm}$ loop sensor) and acquisition performed with a sampling interval of $0.5 \mathrm{~cm}$.

$\mathrm{X}$ ray Computer Tomography $(\mathrm{CT})$ was performed on all cores. Core sections were scanned by a medical CT system under X ray energy of $120 \mathrm{kV}$ and pitch of 0.3 . The final images have a voxel size of $118 / 512 \mathrm{~m}^{3}$ and slice thickness of $1 \mathrm{~mm}$. The intensity of the transmitted 
$\mathrm{X}$ ray beam is strictly related to the density (Duliu, 1999), and is expressed as CT number (Hounsfield unit).

The chemical composition of core CALA 05 was determined by using the Avaatech XRF core scanner under two different settings $(10$ and $50 \mathrm{kV})$. Measurements were performed every $1 \mathrm{~cm}$ along the whole core. Data were plotted after being normalized with $\mathrm{Ti}$, and $\mathrm{Zr}$ was nor malized to $\mathrm{Rb}$.

A total of 151 samples were analyzed for total organic carbon (TOC). Analyses were performed on acidified sediment $(\mathrm{HCl}, 1.5 \mathrm{M})$ to remove the inorganic fraction. Total Carbon (TC) and total nitrogen $\left(\mathrm{N}_{\text {tot }}\right)$ were determined on untreated sediments. Analyses were made with a Finnigan DeltaPlus mass spectrometer directly coupled to a FISONS NA2000 Element Analyzer via a CONFLO interface for continuous flow measurements. TOC and $\mathrm{N}_{\text {tot }}$ contents have been reported as weight percent (wt\%). C/N ratio was calculated as molar ratio between TOC\%and $\mathrm{N}_{\text {tot }} \%\left(14 / 12 *\right.$ TOC\% / $\left.\mathrm{N}_{\text {tot }}\right)$. The accuracy, calculated on atropine analyses, is \pm 0.61 and $\pm 0.11 \%$ for carbon and nitrogen, respectively, while precision is $2.45 \%$ and $1.92 \%$.

Analyses of planktonic and benthic foraminifera were performed on 141 samples (49 from CALA 04, 23 from CALA 05 and 69 from CQ14_02), and were integrated with previously published data on CALA 04 and CALA 05 (Polonia et al., 2013a). All samples, of about $38 \mathrm{~g}$ of dried sediment, $0.51 .5 \mathrm{~cm}$ thick, were dried at $44{ }^{\circ} \mathrm{C}$ for $24 \mathrm{~h}$, weighed, soaked in water, wet sieved through sieves of $63 \mu \mathrm{m}$, dried and weighed again. Foraminiferal analyses were carried out on the size fraction $>63 \mu \mathrm{m}$. Concentration of benthic foraminifera was esti mated in a split portion of $0.03 \mathrm{~g}$ of dry residue $>63 \mu \mathrm{m}$, or on the entire sample if the size fraction $>63 \mu \mathrm{m}$ was $<0.03 \mathrm{~g}$. The identification of fo raminifera is supported by selected key papers such as Banner and Blow (1960), Cita et al. (1974), AGIP (1982), Kennett and Srinivasan (1983) and Rasmussen (2005). Ecological significance of the benthic species was mainly inferred from previous studies in the Mediterranean Sea (Blanc Vernet, 1969; Parisi, 1981; Murray, 1991, 2006; Rasmussen, 2005) (Table 2).

Table 2

Water depth distribution of the main benthic foraminifera in core samples.

\begin{tabular}{|c|c|c|}
\hline Inner shelf & $\begin{array}{l}\text { Wide range of bathymetry } \\
\text { (from shelf to slope) }\end{array}$ & Abyssal \\
\hline $\begin{array}{l}\text { Ammonia spp. } \\
\text { Elphidium spp. } \\
\text { Asterigerinata mamilla } \\
\text { (Williamson, 1858) } \\
\text { Cibicides lobatulus } \\
\text { (Walker \& Jacob, 1798) } \\
\text { Cribroelphidium spp. } \\
\text { Elphidium spp. } \\
\text { Neocorbina terquemi } \\
\text { (Rzehak, 1888) } \\
\text { Nonion depressulum } \\
\text { (Walker \& Jacob, 1798) } \\
\text { Nonionella turgida } \\
\text { (Williamson, 1858) } \\
\text { Rosalina spp. } \\
\text { Valvulineria bradyana } \\
\text { (Fornasini, 1900) }\end{array}$ & $\begin{array}{l}\text { Bolivina spp. } \\
\text { Bulimina spp. } \\
\text { Cassidulina carinata Silvestri, } \\
1896 \\
\text { Cassidulina laevigata d'Orbigny, } \\
1826 \\
\text { Cibicidoides spp. } \\
\text { Fissurina fimbrata (Brady, 1882) } \\
\text { Fissurina orbignyana (Seguenza, } \\
\text { 1862) } \\
\text { Gavelinopsis praegeri } \\
\text { (Heron-Allen \& Earland, 1913) } \\
\text { Globobulimina affinis d'Orbigny, } \\
\text { 1839 } \\
\text { Globocassidulina subglobosa } \\
\text { (Brady, 1881) } \\
\text { Gyroidina umbonata (Silvestri, } \\
\text { 1898) } \\
\text { Gyroidinoides spp. } \\
\text { Lagena elongata (Ehremberg, } \\
\text { 1844) } \\
\text { Lagena laevis (Montagu, 1803) } \\
\text { Lagena striata (d'Orbigny, 1839) } \\
\text { Pullenia quinqueloba (Reuss, } \\
\text { 1851) } \\
\text { Pyrgo spp. } \\
\text { Quinqueloculina viennensis (Le } \\
\text { Clavez \& Le Calvaz, 1958) } \\
\text { Sigmoilina spp. } \\
\text { Uvigerina spp. }\end{array}$ & $\begin{array}{l}\text { Articulina tubulosa } \\
\text { (Seguenza, 1862) }\end{array}$ \\
\hline
\end{tabular}

Mineralogical analyses were carried out on selected samples to de fine sediment composition and sources using Polarized Light Microscope $(\mathrm{PLM})$, immersion liquids $(\mathrm{RI}=1.60)$ and scanning electron microscope with EDS attachment. PLM allowed the identification of the main components (minerals and plant fragments), and SEM/EDS was used to identify minerals and estimate proportions among components.

Radiocarbon ages obtained in previous studies were integrated with new ages to define a chronological framework for the turbidites of this study (Supplementary material SM1). To estimate emplacement time of two newly discovered turbidite beds, three high resolution radiocarbon ages were obtained on planktonic foraminifera sampled from the pelag ic sediment that brackets turbidite beds in core CQ14_02 (Table 3). Ra diometric ages have been used for age modelling in core CQ14_02 through the OxCal software (Bronk Ramsey and Lee, 2013) following the same procedure described in Polonia et al. (2013a) and SM1. The input parameters to generate the age model were the uncalibrated ${ }^{14} \mathrm{C}$ ages and respective $\Delta R$ integrated with ages of ST1, ST2 and ST3 (i.e. AD 1908, 1693 and 1169) with their corresponding corrected depth as deduced from previous studies (Polonia et al., 2013a and SM1). The reg ularity of the sedimentation rate is determined by the $\mathrm{k}$ parameter with the higher values of $\mathrm{k}$ reflecting smaller variations in sedimentation rate (Bronk Ramsey, 2008). For our purposes we chose $\mathrm{k}=3.0$ because we assume that the pelagic sedimentation rate has been constant during the last 1500 years in the study area (Polonia et al., 2013a, 2015). The model finally calculates the age of each corrected depth corresponding to the turbidites of interest and generates the $95.4 \%$ probability age ranges $(2 \sigma)$. In conjunction with ${ }^{14} \mathrm{C}$ dating, pelagic sediment thickness has provided the average time intervals between two successive turbi dite beds ("H method" of Gutiérrez Pastor et al., 2009); correlation with the time elapsed between the proposed triggering earthquakes refined age results. Additional details on ${ }^{14} \mathrm{C}$ data and age modelling are de scribed in Supplementary SM1.

\section{The sedimentary record of turbidites related to historic earthquakes}

Previous multidisciplinary studies of cores CALA 04 and 05 provided proxies to distinguish between pelagic sediment and turbidites and three most prominent turbidite beds in the upper sedimentary se quence were correlated to the AD 1908 Messina, AD 1693 Catania and AD 1169 Eastern Sicily earthquakes (Polonia et al., 2013a and SM1). We label these three turbidite sequences as seismoturbidites (ST), be cause we interpret that they have been generated by the three historic earthquakes. Each of the historic STs is characterized by a cyclic pattern of four units that appear to mark different phases of depositional pro cesses. Building on the previous observations, in this study we intro duce new data from CT scans, high resolution magnetic susceptibility, texture, micropaleontology, TOC and $\mathrm{C} / \mathrm{N}$, to characterize the four units of the STs. Our objective is to understand the quake generated sedimentary processes of the ST units.

\subsection{Core CALA 04 (3845 $m$ water depth)}

Core CALA 04 is located in the abyssal plain of the western Ionian Sea (Fig. 2a) that is fed directly by the westernmost canyon, which extends from the Mt. Etna region downslope along the base of the Malta escarp ment (N. 1 in Fig. 1). The escarpment is cut in this region by a dense net work of short and steep incisions. This Malta Escarpment canyon system intersects one of the three submarine cables (about $60 \mathrm{~km}$ to the south east of the Sicilian coast) that were broken during the AD 1908 Messina earthquake (Fig. 1). A detailed description, top to bottom, of the STs ob served in the uppermost section of core CALA 04 follows (Fig. 3). 
Table 3

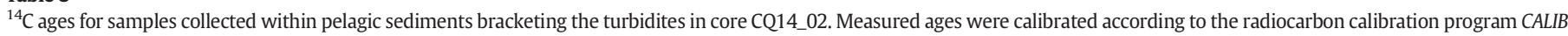
REV6.0.0 (Stuvier and Reimer, 1993) and results are reported both for $\Delta \mathrm{R}=0$ and $\Delta \mathrm{R}=147 \pm 43$.

\begin{tabular}{|c|c|c|c|c|c|c|}
\hline $\begin{array}{l}\text { CQ14_02 core } \\
\text { depth }(\mathrm{cm})\end{array}$ & $\begin{array}{l}\text { Position relative } \\
\text { to the turbidite }\end{array}$ & $\begin{array}{l}\text { Type of } \\
\text { sample }\end{array}$ & Lab. N. & $\begin{array}{l}\text { Measured } \\
{ }^{14} \mathrm{C} \text { age BP }\end{array}$ & $\begin{array}{l}\text { calibrated Age }(2 \sigma) \text { according to CALIB } \\
\text { REV5.0.2 by Stuiver et al. ( } 2005) \\
\Delta \mathrm{R}=0\end{array}$ & $\begin{array}{l}\text { Calibrated age ( } 2 \sigma) \text { with } \Delta R=147 \pm 43 \text { (weighted mean } \\
\text { including } 2 \Delta R \text { in the surrounding regions) }\end{array}$ \\
\hline 1. $210-211$ & $\begin{array}{l}0.5 \mathrm{~cm} \text { below } \\
\mathrm{T} 2 / 2 \text { base }\end{array}$ & Foram & Poz-77891 & $1075 \pm 30$ & AD 12601391 & AD 13221488 \\
\hline 2. $254-255$ & $\begin{array}{l}2 \mathrm{~cm} \text { below ST3 } \\
\text { base }\end{array}$ & Foram & Poz-77889 & $1575 \pm 30$ & AD 724900 & AD 8241080 \\
\hline 3. $256.5-257.5$ & $\begin{array}{l}4.5 \mathrm{~cm} \text { below ST3 } \\
\text { base }\end{array}$ & Foram & Poz-77890 & $1845 \pm 30$ & AD 465647 & AD 591805 \\
\hline
\end{tabular}

\subsubsection{The AD 1908 ST (ST1) is $13 \mathrm{~cm}$ thick and is made up of four units}

Unit ST1a (black, $513 \mathrm{~cm}$ ): CT scan images and CT number provide high resolution information on the fine structure of this turbidite bed, which is not a single unit. Unit ST1a has three different parts shown by high but variable $\mathrm{CT}$ number, TOC, $\mathrm{C} / \mathrm{N}$ and mean grain size (MD) (Fig. 3). The lowermost sandy sub unit ST1a1 (9 to 13 $\mathrm{cm}$ ) is characterized by low TOC and very low $\mathrm{N}_{\text {tot }}$ resulting in a high $\mathrm{C} / \mathrm{N}$, which indicates a more continental input. The upper two sand/silt sub units (ST1a2: $79 \mathrm{~cm}$ and ST1a3: $57 \mathrm{~cm}$ ) have low TOC and low $\mathrm{N}$ resulting in a $\mathrm{C} / \mathrm{N}>10$, which again indicates both are dominated by continental inputs. We call the ST1a unit a stacked seismo turbidite (stacked ST sensu Nelson et al., 2012, 2014) be cause it has three separate turbidite stacks (ST1a1, ST1a2, ST1a3) each with different grain size gradation, sedimentary structures, and composition.

Foraminiferal assemblages in ST1a are size selected and consist of a low amount of small sized $(<125 \mu \mathrm{m})$ planktonic specimens, while rare benthic species are indicative of a wide range of bathymetry and include inner shelf fauna. The finer grained upper part lacks inner shelf fauna.

Unit ST1b (grey, $45 \mathrm{~cm}$ ): This unit shows an increase in TOC and $\mathrm{N}_{\text {tot }}$, and low C/N (more marine sensu Mayer, 1994) (Fig. 4). Only taxa of wide bathymetric range are present in foraminiferal assemblages.

Unit ST1c (dark orange, $23 \mathrm{~cm}$ ): It is marked by mm thick white laminae associated with a decrease in grain size, TOC and $\mathrm{C} / \mathrm{N}$ that is slightly more marine (Fig.4).

Unit ST1d (light orange to beige, $02 \mathrm{~cm}$ ): It is associated with a sand peak, deep water forams only in the basal part, the presence of inner shelf forams and high values of $\mathrm{C} / \mathrm{N}$, all suggesting a more continen tal input.

\subsubsection{The AD 1693 ST (ST2) is $31 \mathrm{~cm}$ thick and is made up of four units}

Unit ST2a (black, 33 45): The high resolution CT scan sedimentary structures, MS and TOC analysis suggest that this ST2a unit is represented by two stacked STa sub units (40 $45 \mathrm{~cm}$ and 3340 $\mathrm{cm})$, al though the sand \% and MD show 3 faint sand gradations (Fig. 3). The basal part of the lower stacked sub unit ST2a1 is characterized by parallel lamination and at its base it is marked by a sharp increase in TOC and high values of $\mathrm{C} / \mathrm{N}$, which decrease upwards. The sedi mentary structures of the CT scan reveal a lower Bouma Tb flat lam inated unit $(4345 \mathrm{~cm}$ ) overlain by an upper Bouma Tc cross laminated unit (40 $43 \mathrm{~cm}$ ). The upper sandy stacked sub unit ST2a2 shows a basal flat laminated Bouma Tb from 37 to $40 \mathrm{~cm}$, with an increase in TOC and C/N. The base of the second stacked tur bidite is marked by a strong peak in MS and an increase in sand con tent which is shown by sand \% and MD. All of the aforementioned data from 37 to $40 \mathrm{~cm}$ confirm the beginning of a new stacked sub unit ST2a2. The Bouma Tb basal part is overlain by Bouma Tc cross laminated sand that grades upward from 33 to $37 \mathrm{~cm}$ as shown by MS and MD data. The overall ST2a unit shows low values of TOC, similar to turbidite ST1a. Foraminiferal assemblages are characterized by a high amount of mainly planktonic specimens, a concentration of inner shelf and a wide bathymetric range of benthic species (Fig. 3). Unit ST2b (grey, $1933 \mathrm{~cm}$ ): This unit shows a gradual decrease in grain size associated with an increase in TOC and $\mathrm{N}_{\text {tot }}$, while $\mathrm{C} / \mathrm{N}$ shows small fluctuations always lower than 10 (Fig. 3). The appear ance of ST2b in the core photo suggests a homogenous mud that has been called homogenite or unifite (Kastens and Cita, 1981; Stanley, 1981). However, the CT scan shows faint lamination, and the grain size plus MS data reveal a continuous textural grading of a turbidite mud, which is typical for homogenite/unifite deposits (Tripsanas et al., 2004). Foraminiferal abundance shows a substantial decrease in this unit. Benthic species are mainly indicative of a wide bathymetric range and inner shelf forams are present throughout the layer. Unit ST2c (orange, $1619 \mathrm{~cm}$ ): It is marked by a basal $1 \mathrm{~cm}$ thick dark orange layer with $\mathrm{mm}$ thick white laminae, no textural grading, a decrease in TOC and $\mathrm{N}_{\text {tot }}$, and a lack of benthic foraminifera (Fig. 3). Unit ST2d (light orange to beige, $1416 \mathrm{~cm}$ ): This unit is homoge nous with no evident internal layering in the CT scan, but the texture shows a slight finer gradation upward. Rare benthic foraminifera are found from a wide bathymetric range.

\subsubsection{The AD 1169 ST (ST3) is $21 \mathrm{~cm}$ thick and is made up of four units} Unit ST3a (black, $5769 \mathrm{~cm}$ ): It is not a single sediment unit but has two stacked STa turbidite sub units. The lowermost sub unit ST3a1 extends from 66 to $69 \mathrm{~cm}$ and is characterized by a silt grain size and apparent Bouma Td flat lamination (i.e. fine grain size), MS with two slightly coarser grain size increases, and $\mathrm{C} / \mathrm{N}$ ratio of about 10 (Fig. 3). The upper sandy silt sub unit ST3a2 from 57 to 66 cm exhibits 3 coarser grain size increases shown by MS and MD, as well as higher TOC and $\mathrm{C} / \mathrm{N}$ ratios compared to the lower sub unit ST3a1. The upper sub unit ST3a2 is characterized by a com plex structure with a possible lower Bouma Tc cross laminated (ob scured by bioturbation?) overlain by a Bouma Td set of undulating laminae and mud chips. The overall ST3a unit shows high values of TOC opposite to turbidites ST1a and ST2a. The high C/N ratios sug gest a more continental origin of the organic matter. Benthic forami niferal assemblages show a wide range of bathymetric assemblages that include inner shelf fauna in the upper part of ST3a2, while the basal part of ST3a1 has no inner shelf fauna, which again confirms the two stacked sub units. Unit ST3b (grey to beige, $5357 \mathrm{~cm}$ ): It is a faintly laminated, graded homogenite turbidite mud that is similar in grain size and homoge neous nature to the ST2b and ST1b grey turbidite muds. However, 


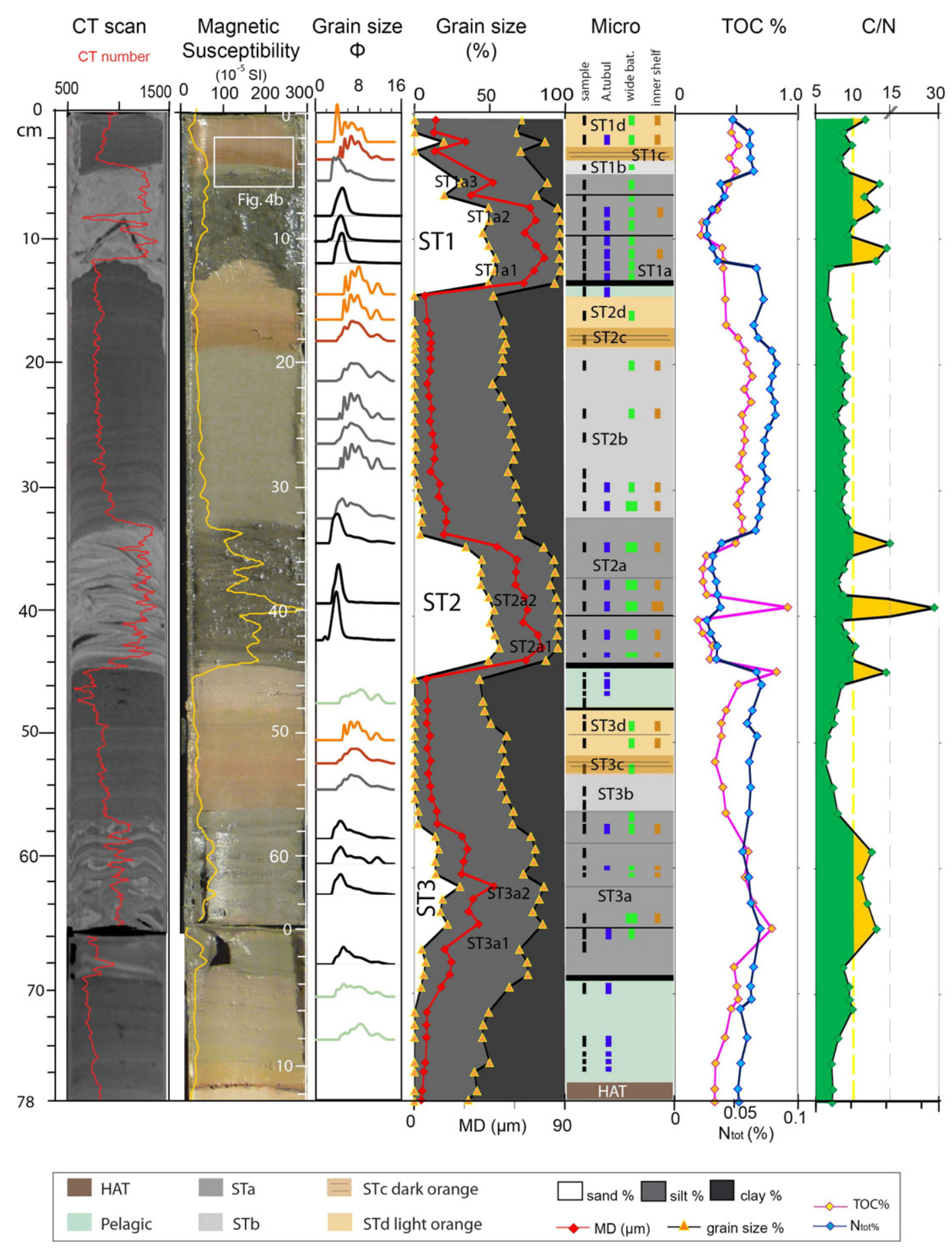

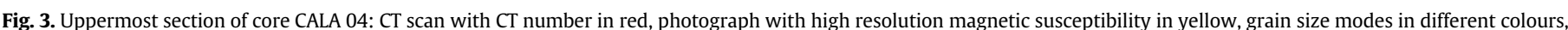

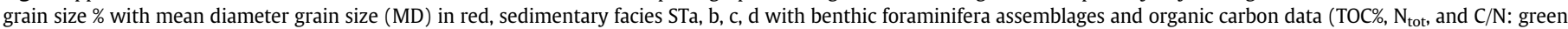

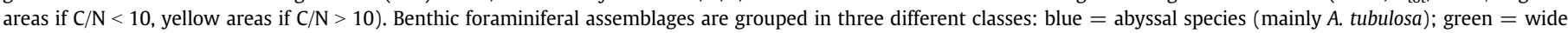

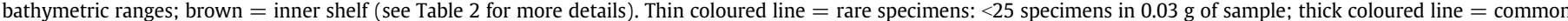

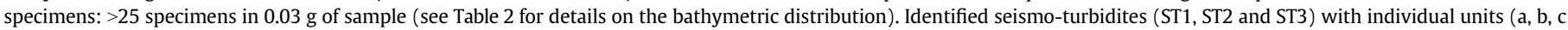
and d) are indicated.

the ST3b unit exhibits a colour change from grey to beige, has lower TOC and lacks benthic foraminifera.

Unit ST3c (dark orange, $5153 \mathrm{~cm}$ ): This unit exhibits flat lamination in the $\mathrm{CT}$ scan, lacks significant grain size gradation and has low C/Nratios (Fig.3).

Unit ST3d (orange to beige unit, $4851 \mathrm{~cm}$ ): This unit is homogeneous without sedimentary structures, shows a silt peak at the base, and a fining upward trend with a gradational increase in clay content, TOC, $\mathrm{N}_{\text {tot }}$ and higher $\mathrm{C} / \mathrm{N}$ ratios. Deep sea benthic foraminifera are absent and inner shelf species are present in ST3d, whereas shelf species are absent in ST3b and ST3c (Fig. 3).

\subsection{Core CALA 05 (3814 $m$ water depth)}

Core CALA 05 is located in a perched basin of the outermost accretion ary wedge close to the abyssal plain but not directly connected to the 


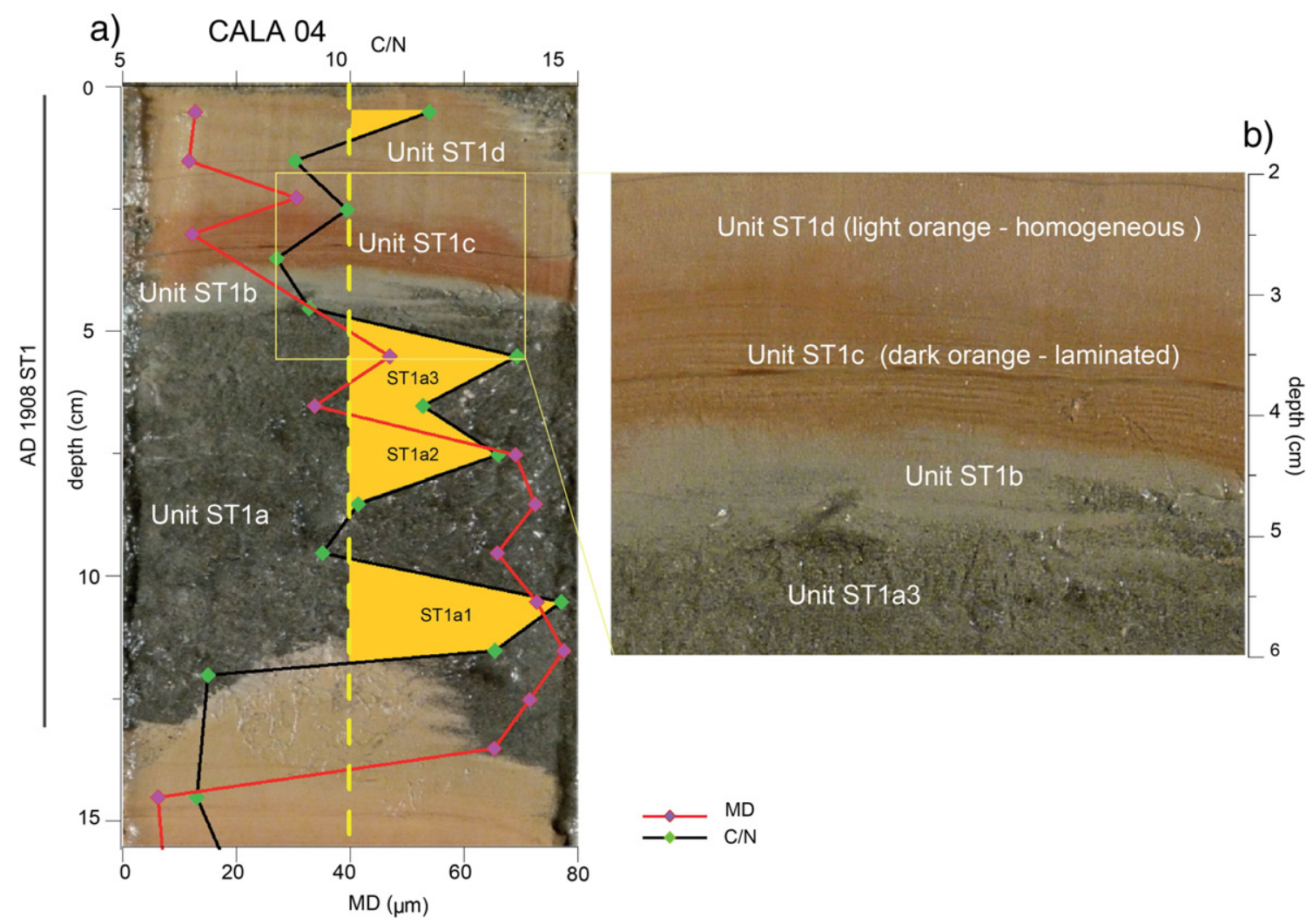

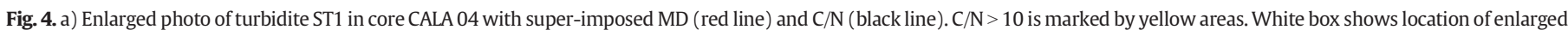

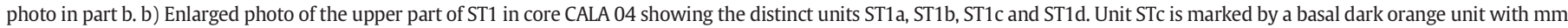
thick white and brown laminae. The light orange upper unit ST1d, on the other hand, is homogenous and does not show any lamination.

canyon systems (Figs. 1 and 2a). In general, the studied section of this core shows thinner basal sand units with a lower sand content (Fig. 5).

\subsubsection{The $A D 1908$ ST (ST1) is $6 \mathrm{~cm}$ thick and is made up of four units} Unit ST1a (black, $56 \mathrm{~cm}$ ): The CT scan shows two peaks suggesting two stacked ST1a sub units (Fig. 5). The core photo also shows two dark sandier units (Fig. 6b), however because of sample spacing, the resolution of the MS, textural and compositional data is not great enough to distinguish 2 sub units. The basal sand is marked by a peaks in $\mathrm{Zr}$ and $\mathrm{Ba}$, as well as low TOC and C/N. Foraminiferal specimens are size selected and consist mainly of a low amount of small sized $(<125 \mu \mathrm{m})$ planktonic taxa and rare benthic, almost en- tirely represented by species indicative of a wide range of bathymetry, from outer shelf to slope.

Unit ST1b (grey, $45 \mathrm{~cm}$ ): This homogenite silt unit has a thickness which varies from 1 to $2 \mathrm{~cm}$ (Fig. 5) and MD shows a rapid decrease in grain size associated with an increase in TOC, N, and $\mathrm{C} / \mathrm{N}$ is $<10$ (Fig. 6a). A few small sized foraminifera are present, mainly plank tonic and rare benthic species indicative of a wide range of bathymetry.

Unit ST1c (orange, $2.54 \mathrm{~cm}$ ): It is marked by a sharp base and a transitional top, faint $\mathrm{CT}$ and $\mathrm{mm}$ thick brown and white laminae as sociated with a slight decrease in TOC and C/N which suggests a more marine sediment source (Fig. 6b).

Unit ST1d (light orange, $02.5 \mathrm{~cm}$ ): Light orange to beige homoge neous sediments are associated with values of $\mathrm{C} / \mathrm{N}>10$ and with an increase in $\mathrm{Fe}, \mathrm{Al}$ and $\mathrm{Mn}$, all of which suggest a more continental input (Figs. 5 and 6). ST1c and ST1d are almost barren in foraminifera.

5.2.2. The AD 1693 ST (ST2) is $13 \mathrm{~cm}$ thick and is made up of four units Unit ST2a (black, $1921 \mathrm{~cm}$ ): The high resolution CT scan, MS, TOC and $\mathrm{C} / \mathrm{N}$ data suggest that this unit is represented by two stacked turbidite sub units (19 20 and $2021 \mathrm{~cm}$ ), although the MD grain size resolution is not great enough to show this (Figs. 5 and 6a). Each stack exhibits mm scale parallel laminations that probably rep resent Bouma Td sedimentary structures. The lower stacked ST2a1 sub unit has lower TOC and C/N while the upper stacked ST2a2 sub unit shows high TOC contents and $\mathrm{C} / \mathrm{N}>10$, which suggests a more continental source for the upper turbidite stack. ST2a1 is char acterized by high Zr and Ba concentrations, which again suggest two different sources for the ST2a1 and ST2a2 subunits (Fig. 5). Forami niferal assemblages are size selected and consist mainly of a low amount of small sized $(<125 \mu \mathrm{m})$ planktonic taxa and rare benthic species, that mainly indicate a wide range of bathymetry, including inner shelf and abyssal taxa. Unit ST2b (grey, $1219 \mathrm{~cm}$ ): The grey homogenite clayey silt exhibits faint parallel $\mathrm{mm}$ thick laminae at the base and becomes homogeneous at its top (Fig. 5). This unit shows a gradual decrease in grain size associated with an increase in TOC and $\mathrm{N}_{\text {tot }}$ in its upper part where a high value of $\mathrm{C} / \mathrm{N}$ suggests a more continental input of organic matter. Foraminifera are rare and characterized mainly by small sized planktonic species in association with benthic taxa indicative of a wide range of bathymetry (shelf to slope). 


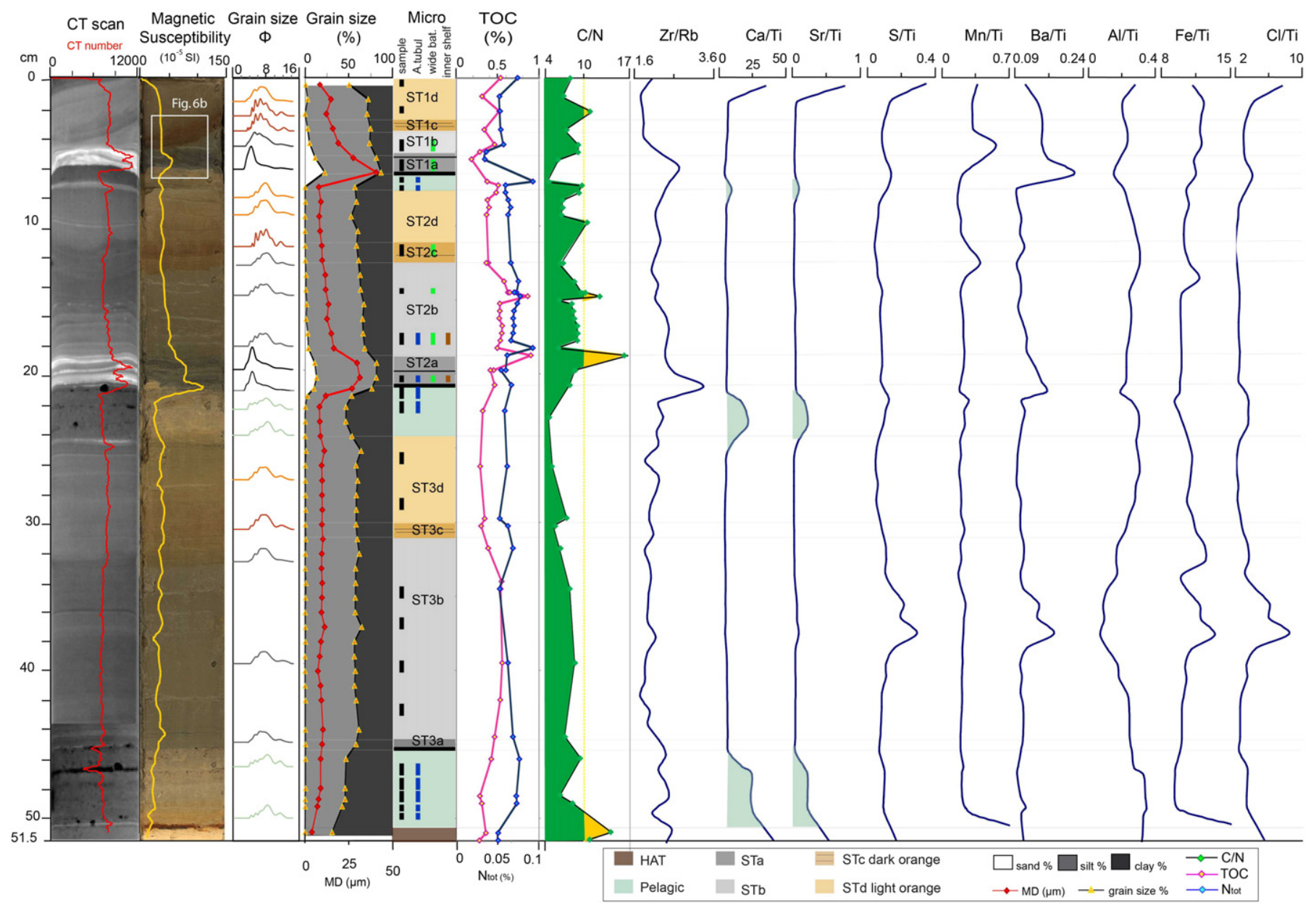

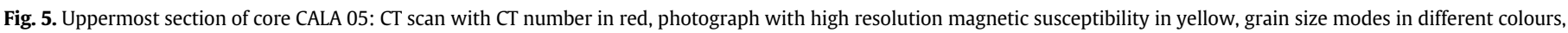

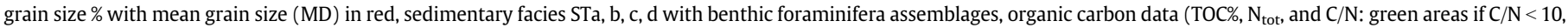

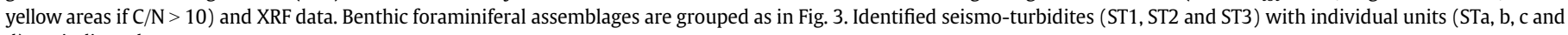
d) are indicated.

Abyssal (Articulina tubulosa) and inner shelf foraminifera are pres ent only in the lower part of the unit. Unit ST2c (orange, $1112 \mathrm{~cm}$ ): Unit ST2c is marked by a dark orange layer that exhibits faint laminations in the CT scan (Fig. 6).

This layer is associated with a decrease in TOC and C/N, which suggest a more marine provenance of the organic matter. Unit ST2d (light orange $811 \mathrm{~cm}$ ): This unit is associated with in creased TOC and C/N values and higher values of $\mathrm{Mn}, \mathrm{Fe}$ and $\mathrm{Al}$, all of which suggest a more continental source of the sediment. ST2c and ST2d are almost barren in foraminifera with only rare planktonic and very rare benthic specimens indicative of wide range of bathymetry.

\subsubsection{The AD 1169 ST (ST3) is $21 \mathrm{~cm}$ thick and is made up of four units}

Units ST3a and ST3b (black grey, $3145 \mathrm{~cm}$ ): The ST3 is much finer grained than the ST1 and ST2 of CALA 5, which results in more subtle changes in texture and composition to distinguish different parts of layer ST3. At the base of the layer, from 44 to $45 \mathrm{~cm}$, the CT scan shows mm scale lamination and two coarser grained peaks and this plus an MS peak correlative with the upper CT peak suggest that the two turbidite stacked sub units make up the ST3a (Fig. 5). Above the ST3a thin base, a thick ST3b homogenite silt is found from 31 to $44 \mathrm{~cm}$. There are few compositional or faunal characteristics that distinguish it because there is no sand fraction and it is barren of benthic foraminifera with only small planktonic specimens present. The upper part of ST3b does show increased S, $\mathrm{Ba}$ and $\mathrm{Mn}$ content associated with an increase in $\mathrm{Cl}$, which may suggest an increased water content.

Unit ST3c (orange, $3031 \mathrm{~cm}$ ): This entire unit exhibits higher CT numbers, although the grain size is similar to the underlying ST3b unit. Unit ST3d (light orange, $2430 \mathrm{~cm}$ ): An increase in Fe and $\mathrm{Al}$ is located at the base of the ST3d unit, which is also associated with variations in values of TOC, $\mathrm{N}_{\text {tot }}$, and higher C/N. ST3C and ST3d are substantially barren with only small planktonic foraminifera.

\subsection{Core CQ14 02 (3356 m water depth)}

Core CQ14_02 was collected in a slope terrace, within a ponded closed basin at a canyon mouth (Figs. 1 and $2 \mathrm{~b}$ ). This small basin is bounded to the east by a structural high and to the west by folds belong ing to the outer accretionary wedge. This area is fed by canyons connect ed with the Calabrian and Sicilian shelves, and these canyons die out in the flat region of the slope terrace without reaching the abyssal plain. Because of the containment caused by structural highs, this terrace set ting results in the highest sand content, the maximum thickness of the turbidite beds, an expanded record of the STs and deposits that show other minor turbidite events. 


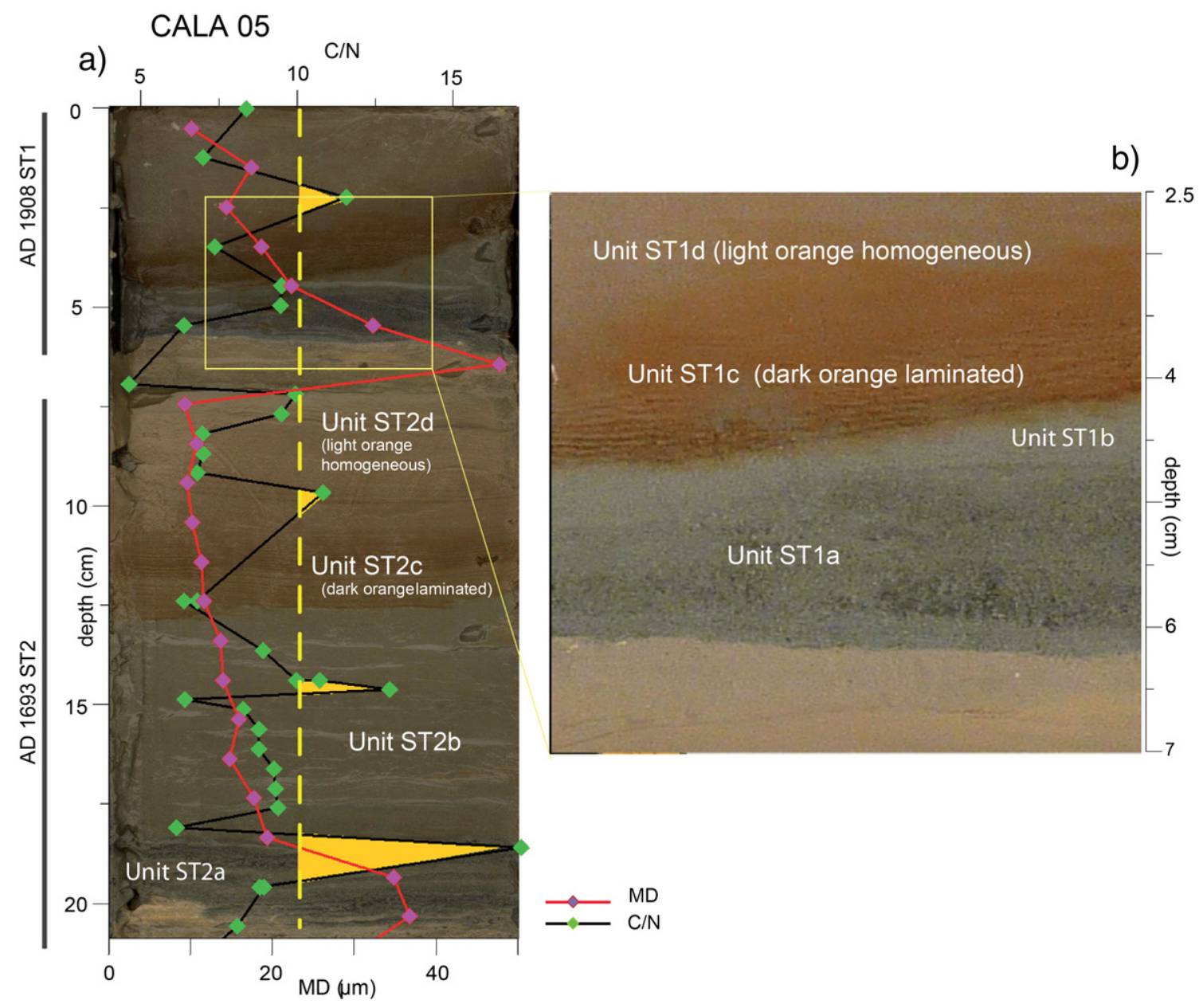

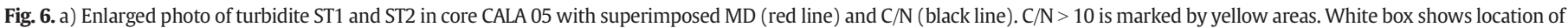

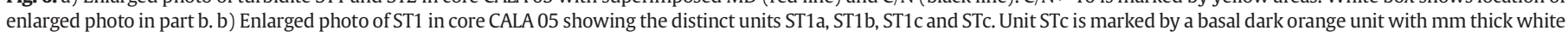
and brown laminae. The light orange upper unit STc is homogenous graded mud and does not have lamination.

The turbidite beds exhibit the same STa, b, c, d units as other core lo cations (black at the base, grey and orange to beige at the upper part), however these colours are not so distinct as in the other cores locations. In the uppermost $270 \mathrm{~cm}$ of the core, we observe five turbidite beds (Fig. 7).

\subsubsection{The AD 1908 ST (ST1) is $134 \mathrm{~cm}$ thick and is made up of four units}

Unit ST1a (black, $22134 \mathrm{~cm}$ ): ST1a is about $112 \mathrm{~cm}$ thick and is marked by a sharp erosional base where the sand content increases abruptly to about $80 \%$ and then decreases rapidly to $<50 \%$ at $64 \mathrm{~cm}$ (Fig. 7). The basal ST1a exhibits parallel laminations and a gradually fining upward trend in the MD, which stops at about $104 \mathrm{~cm}$ bsf. At $104 \mathrm{~cm}$, chaotic sediment structures with contorted sand lenses ap pear and are associated with a new input of higher sand and a coars er MD (Fig. 7). The contorted sand bed continues from $104 \mathrm{~cm}$ to $60 \mathrm{~cm}$ with 4 sand peaks. From 22 to 60 $\mathrm{cm}, \mathrm{mm}$ scale dark and light lamina are observed in the CT scan (Bouma Td related to the upper sand sub unit?), but these are pulled down several centimeters along the right side of the core barrel. The greater core disturbance related to coarser sand, the pulled down laminae from 22 to $60 \mathrm{~cm}$, and the highly disturbed sediment at the top of the core above this, all suggest that severe coring disturbance has affect ed the core above $104 \mathrm{~cm}$ and that the STa unit is not an MTD.

In sum, two STa stacked turbidite sub units (ST1a1: $104134 \mathrm{~cm}$ and ST1a2: $22104 \mathrm{~cm}$ ) appear to characterize the ST1a unit (Fig. 7). The CT scan, TOC and $\mathrm{N}_{\text {tot }}$ (low for ST1a1 and high for ST1a2), $\mathrm{C} / \mathrm{N}$ (>10 for the entire ST1a but higher for the upper turbidite stack ST1a2), MS, and grain size data also suggest there are two turbidite stacks with different compositions related to separate failure sources. Fora miniferal assemblages are dominated by planktonic taxa in associa tion with benthic species indicative of a wide bathymetric range. Abyssal taxa are present only in a few samples in the middle of ST1a2 while inner shelf taxa are present in the upper part of ST1a1 and within the lower part of ST1a2 (Fig. 7).

Unit ST1b (grey, $1222 \mathrm{~cm}$ ): This clayey silt homogenite shows a gradual decrease in grain size associated with low TOC, increased

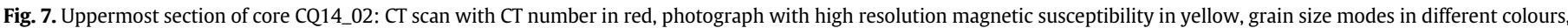

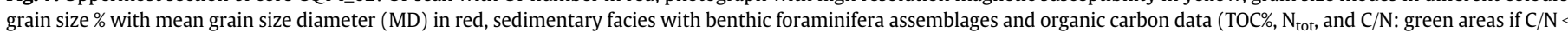

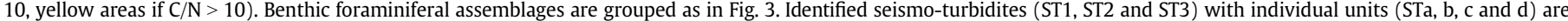
indicated. 





$\mathrm{N}_{\text {tot }}$ and $\mathrm{C} / \mathrm{N}<10$ (Fig. 7). Foraminiferal assemblages include mainly planktonic taxa in association with rare benthic species that repre sent a wide bathymetric range. An orange to beige unit is $12 \mathrm{~cm}$ thick and is marked by a slight in crease in sand content (Fig. 7). The unit is highly disturbed, however from 8 to $12 \mathrm{~cm}$ there may be a slightly darker unit with parallel lam inae (ST1c) and another possible lighter orange unit above (ST1d), but no sedimentary structures can be defined. Foraminiferal assem blages are characterized by low number of specimens, mainly plank tonic, with the occurrence of rare benthic species that represent a wide bathymetric range. A few abyssal foraminifera are present in the uppermost part of the unit close to the seabed (Fig. 7).

5.3.2. The T1/2 turbidite bed is $11 \mathrm{~cm}$ thick and made up of four units

The T1/2 turbidite is an additional turbidite, that is not present in the other CALA 04 and 05 cores and that is found between the AD 1908 and AD 1693 STs. It is $12 \mathrm{~cm}$ thick and shows the same four units as in the other turbidite beds (black, grey, orange and beige) (Figs. 7 and $8 \mathrm{a}$ ). T1/2 is marked by a sharp sandy base (ST1/2a, from 141 to $145 \mathrm{~cm}$ ) with two distinct sand peaks characterized by $\mathrm{C} / \mathrm{N}>10$. The grey unit (ST1/2b, from 138 to $141 \mathrm{~cm}$ ) shows a fining upward sequence. The upper orange unit shows a darker level (ST1/2c, from 136 to $138 \mathrm{~cm}$ ), which exhibits mm thick laminae (Fig. 8a) while the light orange unit above it (ST1/2d, from 134 to $136 \mathrm{~cm}$ ) is rather homogeneous. Forami nifera are rare and represented by small planktonic species; the sandy base also includes benthic species indicative of wide bathymetric range and the abyssal environment.

\subsubsection{The AD $1693 \mathrm{ST}$ (ST2) is $54 \mathrm{~cm}$ thick and made up of four units}

Unit ST2a (black, $179198 \mathrm{~cm}$ ): Similar to other core locations, ST2a contains two stacked turbidite sub units (ST2a1 from 179 to 188 and ST2a2 from 188 to $198 \mathrm{~cm}$ ) that are shown by MD, MS and sand \%. The ST2a1 exhibits possible faint cross lamination (Bouma Tc?) overlain by mm scale flat lamination (Bouma Td?) (Fig. 7). The ST2a2 exhibits mm scale flat lamination throughout. $\mathrm{C} / \mathrm{N}$ is $>10$ for ST2a 1 and is $<10$ for ST2a2. Foraminiferal assemblages consist main ly of planktonic taxa in association with common benthic species that indicate a wide bathymetric range, including the abyssal environment. Inner shelf species are locally observed only in the upper turbidite stack.

Unit ST2b (grey, $151179 \mathrm{~cm}$ ): This clayey silt homogenite exhibits faint lamination and a gradual decrease in grain size. The TOC is rather constant throughout this unit while $\mathrm{N}_{\text {tot }}$ increases upwards pro viding a decrease in $\mathrm{C} / \mathrm{N}$ to values $<10$. The observed foraminifera are mainly planktonic in association with rare benthic species that indicate a wide bathymetric range. Abyssal specimens are present in the lower part of the unit. Unit ST2c (dark orange, $149151 \mathrm{~cm}$ ): This unit shows faint laminations.

Unit ST2d (light orange to beige, $144149 \mathrm{~cm}$ ): It is a homogeneous clayey silt unit. $\mathrm{C} / \mathrm{N}$ and TOC do not show any variation relative to the units below. Foraminifera are rare and include only small sized planktonic species.

5.3.4. The T2/2 turbidite bed is $14 \mathrm{~cm}$ thick and made up of two units The T2/2 turbidite has been emplaced between the AD 1693 and AD 1169 events and is not present in the CALA 04 and 05 cores. This bed dif fers from previously described turbidites because it does not have turbi dite stack sub units and lacks the STc and STd units. The base of this turbidite bed is not as sharp, the included units are not as clearly defined and transitions are more gradual compared with the other turbidites (Fig. 8b). A single basal sandy silt unit extends from 206 to $212 \mathrm{~cm}$, has classic simple fining up texture shown by the CT scan and MD, con tains up to $10 \%$ sand, and exhibits faint lamination (Fig. 7). Above the basal unit, a light grey to beige clayey silt unit is found from 198 to $206 \mathrm{~cm}$. No darker orange unit with $\mathrm{mm}$ thick laminae is present. Both TOC and Ntot show an increase at the base of the turbidite, which results in low $\mathrm{C} / \mathrm{N}$ values, especially in the grey to beige unit. Foraminiferal assemblages include mainly planktonic taxa in association with rare benthic species in the lower part of the unit that represent a wide bathymetric range and the abyssal environment.

\subsubsection{The AD $1169 \mathrm{ST}$ (ST3) is $46 \mathrm{~cm}$ thick and is made up of four units}

Unit ST3a (black, $226259 \mathrm{~cm}$ ): ST3a has a sharp base and parallel lamination and contains 2 sub units shown by MD sand peaks from 251 to $259 \mathrm{~cm}$ (ST3a1) and another from 226 to $246 \mathrm{~cm}$ (ST3a2) which has a sandy silt tail extending to $226 \mathrm{~cm}$ (Fig. 7). ST3a1 includes more benthic species than ST3a2, and inner shelf species are present in ST3a1. The different sub units are associated with differences in composition (TOC, C/N, foraminifera) and these observations indicate that the ST3a unit consists of two sub units as observed for core CALA 04.

Unit ST3b (grey, 220 226): It consists of a homogenous clayey silt with a slight upward increase in clay (Fig. 7) and a decrease in sand contents. Foraminiferal assemblages consist mainly of small planktonic taxa in association with rare benthic species that indicate a wide bathymetric range.

Units ST3c and ST3d (from 218 to $220 \mathrm{~cm}$ and $213218 \mathrm{~cm}$ ): They show a homogeneous texture and exhibit some lamination but bio turbation has disrupted primary structures. Both units have rather constant TOC and $\mathrm{N}_{\text {tot }}$ values and low C/N. Foraminifera only include small sized planktonic species and very rare benthic specimens in dicative of wide range of bathymetry.

In core CQ14_02 we selected three ${ }^{14} \mathrm{C}$ samples within pelagic inter vals in order to determine emplacement time for the new turbidite beds T1/2 and T2/2 (Fig. 7 and Table 3). Age modelling through OxCal soft ware (Bronk Ramsey and Lee, 2013) provides a representative set of possible ages for turbidites $\mathrm{T} 1 / 2$ and $\mathrm{T} 2 / 2$ that are respectively AD 17151909 and AD 13441632 (Fig. 9).

\section{Processes generating Ionian Sea turbidites}

Intense tectonic activity and dynamic topography of the Calabrian Arc produce a strong interplay between seismic shaking, sediment fail ures, turbidity currents and tsunami generation in the Ionian Sea. During historic times, episodic deposits on the basin floors are generated by earthquakes (Polonia et al., 2013a, 2013b, 2016a) but major issues that deserve further analysis include: i) the complexity of the sedimen tary record and of the seismic sources; ii) the sensitivity of core location in linking individual deposits related to a specific earthquake; iii) the earthquake magnitude threshold in triggering mass flows; and iv) the relative contribution of seismic shaking and tsunami wave processes re lated to generation of STs. In addition, other triggers for turbidity cur rents besides earthquakes (i.e. random slope failures, storms, cyclones and flash floods) need to be taken into account especially for those tur bidites that do not show a large areal extent like turbidites $\mathrm{T} 1 / 2$ and $\mathrm{T} 2 / 2$. We will discuss next, how our multi proxy approach aimed at defin ing age, source and emplacement mechanism of each turbidite event, may give insights to address all these issues.

The deposition of turbidites can be linked to a number of different triggering processes (e.g. Piper and Normark, 2009; Talling, 2014) such as storms (Mulder et al., 2001), tsunamis (Kastens and Cita, 1981; Shanmugam, 2011; Polonia et al., 2016a), hyperpycnal flow (Mulder et al., 2003; Casalbore et al., 2011), gas hydrate destabilization 


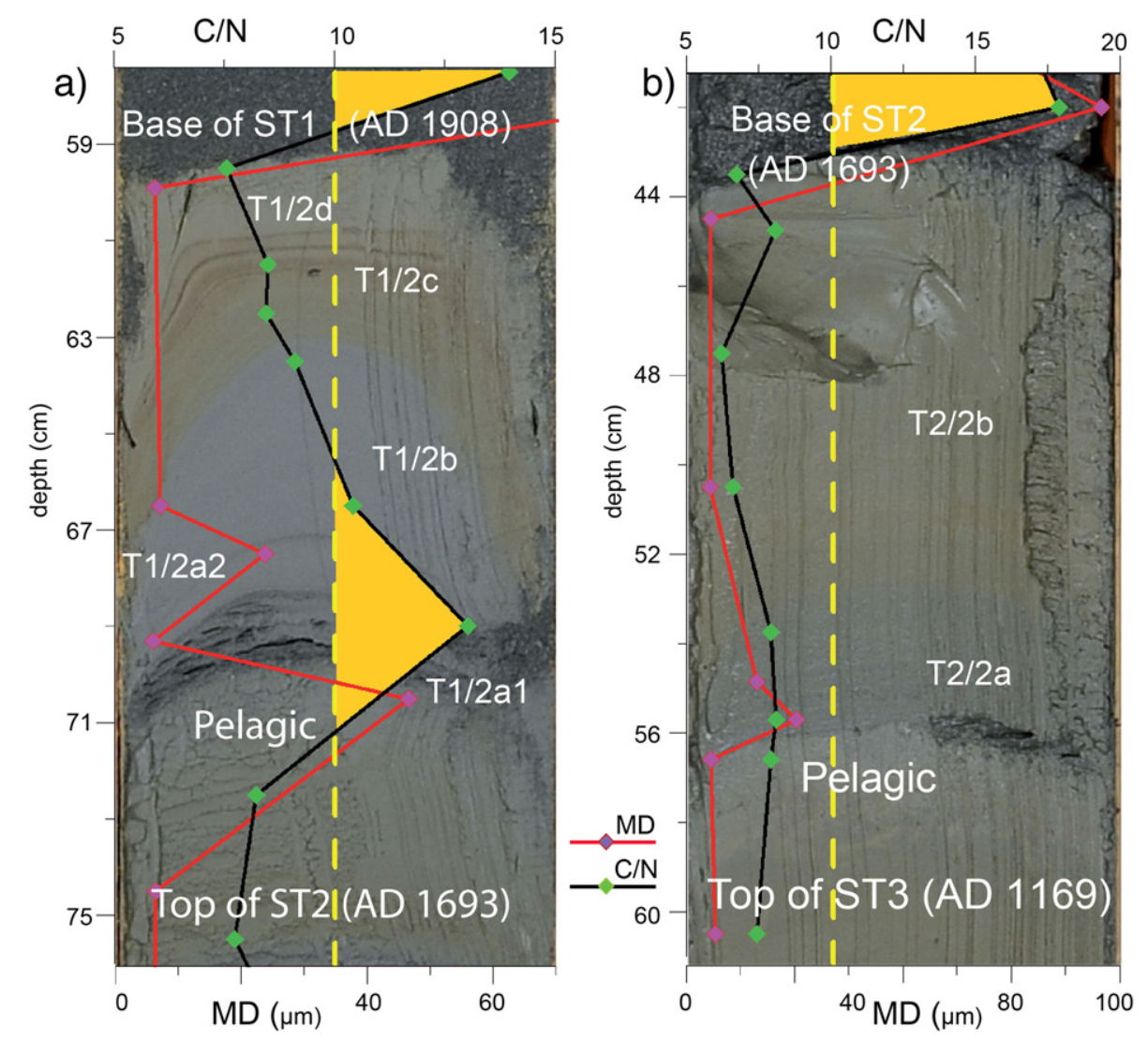

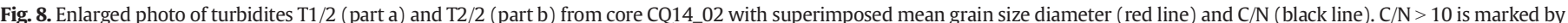

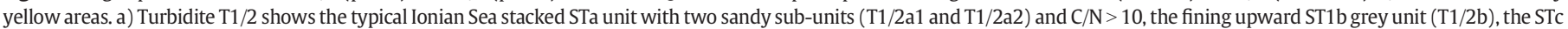

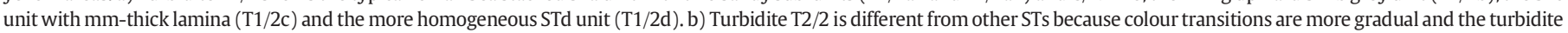
only has basal sand units (T2/2a) and a Tb homogenite unit (T2/2b) with no visible Tc or Td overlying the Ta and Tb units.

(Rothwell et al., 1998), earthquakes (e.g. Adams, 1990; Nelson et al., 2000; Goldfinger et al., 2012) or a combination of these processes.

During the last decades tropical like cyclones have occurred frequently in the Ionian Sea (Miglietta et al., 2011). Thus these storms may be considered as potential triggers for mass flows and turbidity current generation in the study region as has been suggested but not proven for typhoon floods off Taiwan (Carter et al., 2012). The dimension of the Ionian study area is also important in this regard, because we are dealing with a relatively small area with canyons only tens of $\mathrm{km}$ apart. This implies that one single cyclonic storm could have affected the entire study area and the principle of synchroneity usually applied in oceanic regions to unravel a seismic trigger (Goldfinger et al., 2003a, 2012) may not be valid here. However, available data suggest that a storm or flood trigger for our STs is unlikely and here we list major observations against this link.

Major storms occurred in the Ionian Sea in 1999, 2000, 2004, 2008 and the most intense one in 2012 with a minimum pressure of about $980 \mathrm{hPa}$ (Miglietta et al., 2011). Our post storm cores (e.g. CQ14_02) do not show any turbidite bed that could be related to the 2012 storm.

Flash floods also develop in the ephemeral streams that are found in the mountainous relief facing the Messina Strait region. These streams are characterized by a short length, extremely steep valleys and a high energy hydraulic regime during flash floods and thus are poten tially capable of generating debris flows (Casalbore et al., 2011). On Oc tober 1, 2009 the northeastern Sicily coast was struck by major flash floods and widespread landslides in the catchment area of steep subaer ial creeks. Debris flows hit the coastal villages, entered the sea and pro duced mass wasting events and retrogressive slope failures. However, such effects were observed only in shelf and upper slope (Casalbore et al., 2011). Our post flood cores in deep water basins show no evidence of the 2009 mass flows suggesting that flash floods events may produce debris flow in the shallow areas, but are not likely to trigger turbidity currents that travel down to the abyssal plain and deep slope basins.

Frequent storm induced sediment gravity flows also are described at the head of the Eel submarine canyon, but not down canyon (Puig et al., 2004). In the Eel Canyon mouth, Paull et al. (2014) observed that turbidites were emplaced on average every $\sim 36$ years during the early Holocene lower sea levels, although the average frequency over 12,000 years is much less in the deep sea downstream channel ( 246 years), which is a frequency similar to that of the Cascadia earth quake frequency in this area (Nelson et al., 2000; Goldfinger et al., 2012). Like the Eel fan region, the frequency of storm and floods in the Ionian Sea is very high but deep sea turbidites repeat every 100 700 years (Polonia et al., 2015) implying that a less frequent trigger generates the deep sea turbidites.

In the Ionian Sea, similar to other active tectonic margins, the frequency of catastrophic floods and storms does not agree with the frequency of turbidites in the abyssal sea floor deposits. Turbidite frequency most often coincides with earthquake frequency in locations such as offshore from the Cascadia subduction zone (turbidites and earthquakes 1/ 500 years) (Nelson et al., 2000; Goldfinger et al., 2012), the northern San Andreas Fault (turbidites and earthquakes 1/ 200 years) (Goldfinger et al., 2007; Gutiérrez Pastor et al., 2009), Hikurangi margin in New Zealand (Pouderoux et al., 2012a, 2012b), Chile subduction zone (Moernaut et al., 2014) and Sumatra (Patton et al., 2015). For example, along the Cascadia Subduction Zone and North ern San Andreas Fault margins for the past 10,000 years, the average turbidite recurrence times are different (530 and 200 years respectively the same as onshore paleoseismic recurrence times), although the same 


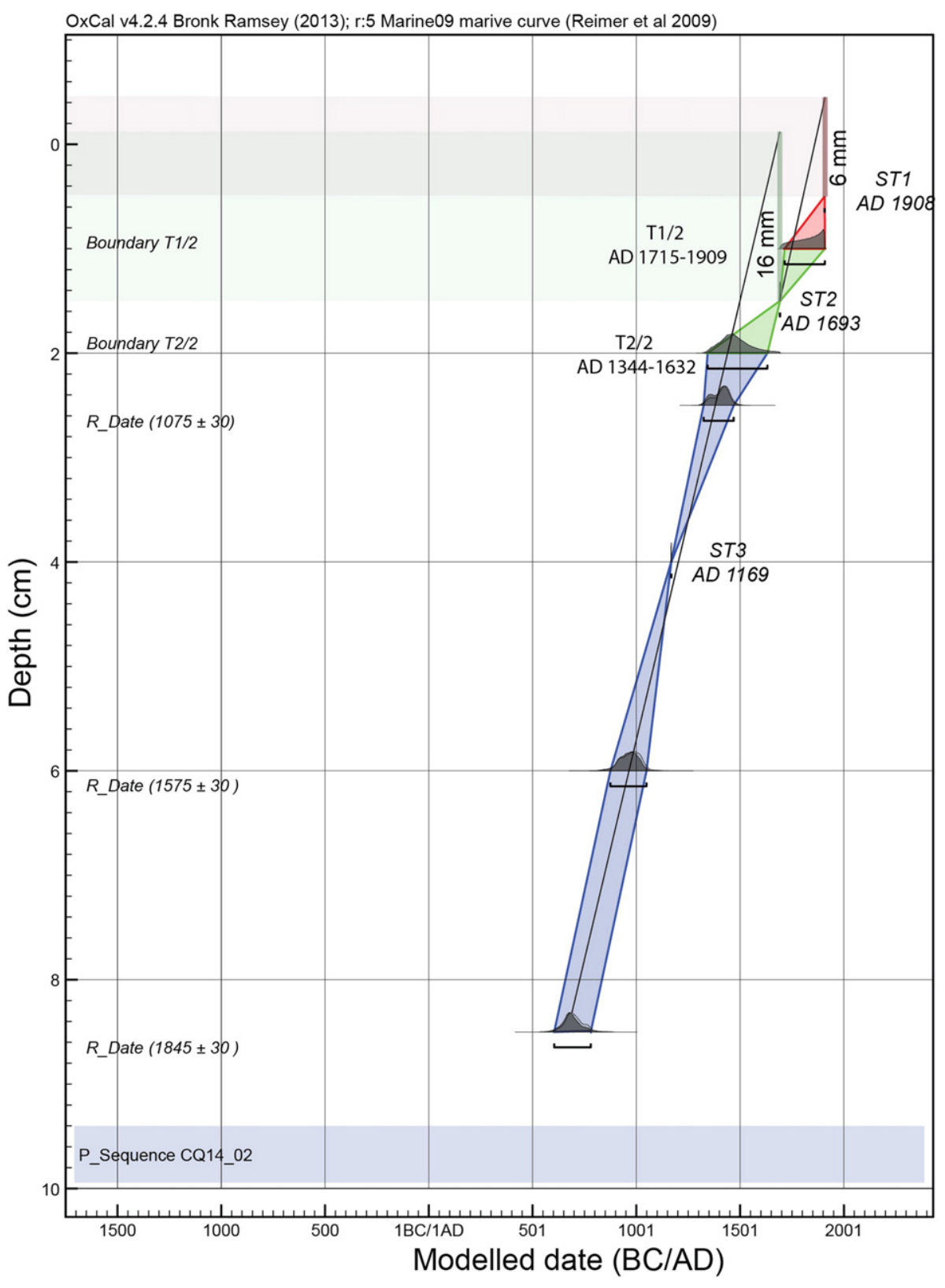

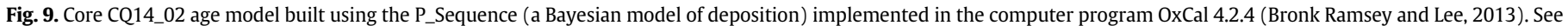

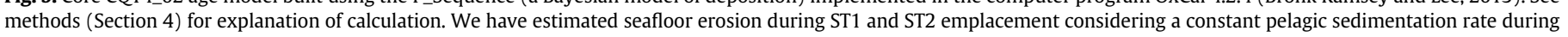

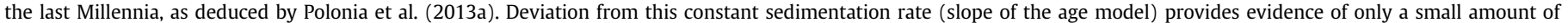
seafloor erosion ( $0.6 \mathrm{~cm}$ and $1.6 \mathrm{~cm}$ during the ST1 and ST2 emplacement respectively).

frequent storms and el Niño floods have hit both areas (Goldfinger et al., 2008; Gutiérrez Pastor et al., 2009).

Along the New Zealand margin for the past 18,000 years during high and low sea levels, only $3 \%$ of the 77 turbidites have been deposited by floods and storms, whereas all the others are seismoturbidites (Pouderoux et al., 2012a). In sum, along tectonically active margins, earthquakes appear to be the dominant triggering mechanism for turbi dites at centennial timescales (e.g. Nelson et al., 2012, 2014; Pouderoux et al., 2012b; Polonia et al., 2013a, 2013b).

\section{Correlation between STs and seismic events}

Turbidites can potentially provide a valuable long term record of major earthquakes. STs are generally characterized by wide areal extent, multiple sand/silt pulses (sub units of coarser grain size) with variable provenance, plus greater volumes, thickness and grain size than storm generated events (Nakajima and Kanai, 2000; Shiki et al., 2000; Gorsline et al., 2000). The most conclusive proof for STs that cannot be correlated with historic earthquakes is the synchronicity of correlative turbidites over thousands of $\mathrm{km}^{2}$ as shown by stratigraphic correlations (Adams, 1990; Nelson et al., 2000; Gutiérrez Pastor et al., 2009), high resolution radiocarbon ages (Goldfinger et al., 2003a, 2007), and physi cal properties (Goldfinger et al., 2012). However, widespread slope fail ure has been suggested as the only criteria for inferring seismic triggering (Talling, 2014), even though it is difficult to obtain accurate radiocarbon ages to prove this.

Turbidite beds in the Ionian Sea exhibit all of the sedimentological characteristics considered typical of STs: multiple sand pulses; variable provenance as deduced from foraminiferal distribution, mineralogy and TOC; large thickness up to $135 \mathrm{~cm}$; sand content up to $80 \%$, and wide 


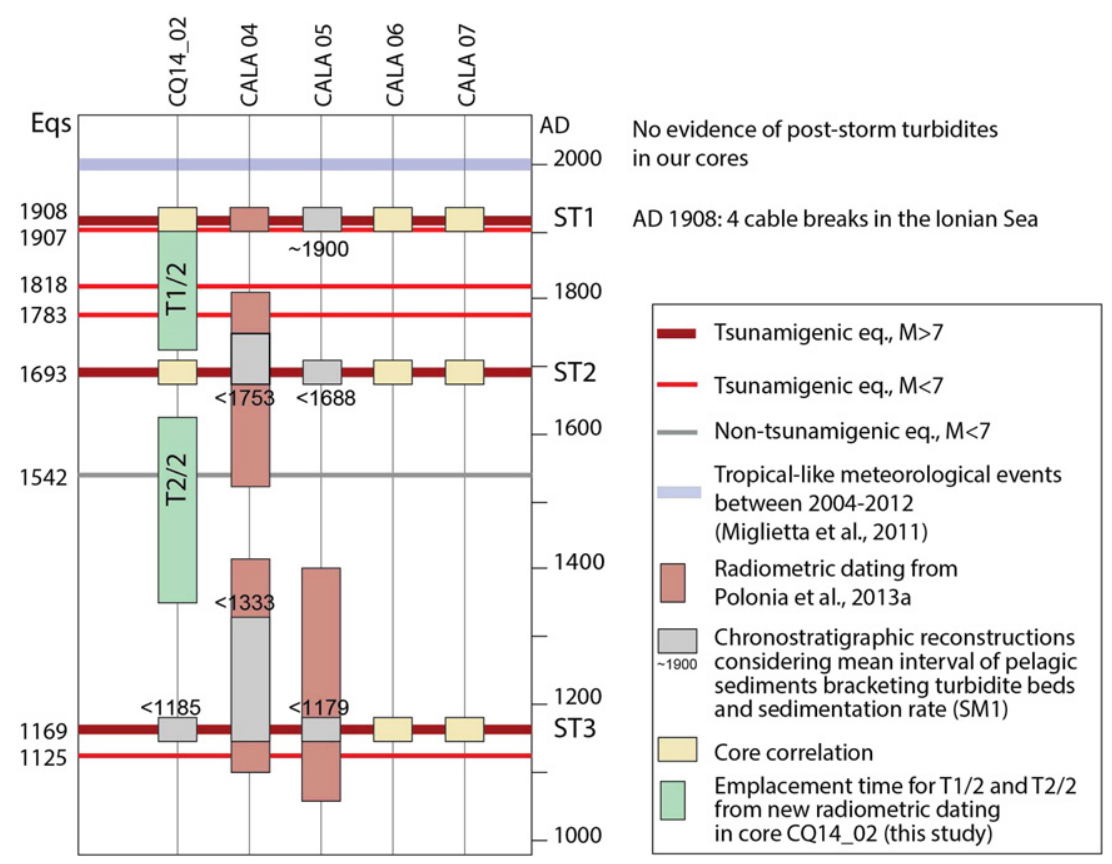

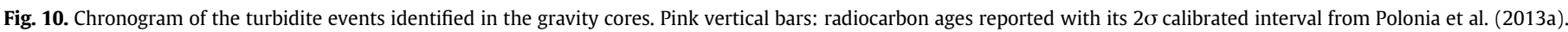

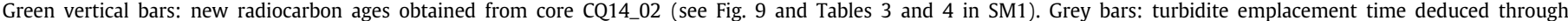

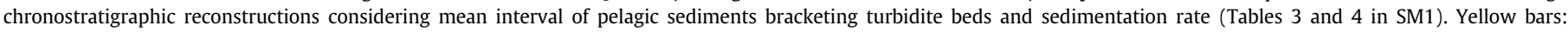

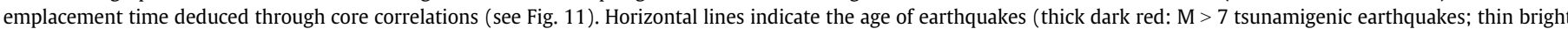

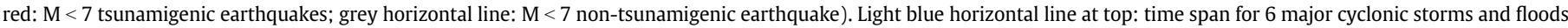
between AD 2004 and 2012 (Miglietta et al., 2011), with no post-cyclone turbidites observed in cores taken after 2012.

areal extent compared to known storm or river sourced turbidites. However, the most robust proof of a seismic trigger for the Ionian STs, is the synchronicity of turbidite emplacement time and historical earth quakes ages that are shown by radiometric and chronostratigraphic dating in cores CALA 04, CALA 05 and CQ14_02 (Fig. 10, SM1). This ST interpretation is further supported by a number of different observations:

i) The average time interval between successive turbidite beds cal culated from the thickness of pelagic sediment bracketing turbidites and sedimentation rate agrees with the time interval between major earthquakes (SM1) (Polonia et al., 2013a).

ii) The presence of stacked STa sand/silt sub units is compatible with multiple synchronous submarine failures and turbidity cur rents triggered by an earthquake. This interpretation is confirmed by our new high resolution compositional analyses, which include mineralogy, $\mathrm{C} / \mathrm{N}$, foraminifera assemblages and geochemistry (Figs. 3 to 8, SM2 to SM4). Moreover, for the AD 1908 event different cable breaks occurred immediately after the earthquake suggesting the generation of multiple slope failures and turbidity currents that affected different canyon systems (Fig. 1).

iii) Cyclones and storms have a short recurrence times whereas abyssal turbidites repeat every several hundred years similar to earthquake timing.

iv) Although a number of intense storms and flash floods with associated upper slope failures have occurred in the study region dur ing the past 20 years (Miglietta et al., 2011), our deep sea cores do not show any turbidites correlated with these events.

The historical information indicates that ST1 was generated by the AD 1908 Messina earthquake. Radiometric and chronostratigraphic ages show that ST1 was emplaced immediately after 1900 (Polonia et al., 2013a). The AD 1908 Messina earthquake generated turbidity currents, which broke submarine cables in sequence as these flows travelled downslope (Fig. 1). The time elapsed between two successive cable breaks was used to estimate turbidity current velocity of $67 \mathrm{~m} / \mathrm{s}$ (Ryan and Heezen, 1965). Analysis of sediment composition indicates that the source area for ST1 includes low to medium grade metamorphic rocks, like those outcropping in Calabria and Sicily near the Messina Strait where the first cable break and generating earthquake fault are found (Fig. 1, SM2 to SM4) (Polonia et al., 2012, 2013a, 2016b).

We interpret that ST2 was generated by the strongest recent Catania earthquake ( $\mathrm{Mw}=7.41 \mathrm{AD}$ 1693), which deposited the thickest ST bed on the abyssal plain (Fig. 3). The maximum thickness of ST2 in the abys sal plain suggests that the canyon system at the base of the Malta es carpment is the major pathway for ST2 (canyon system N. 1 in Fig. 1). In contrast, the main contribution of sediment deposited in ST1 comes from the canyon system N. 2 in the central part of the study area (Fig. 1). However, in both ST1 and ST2 more than one canyon system was ac tive as demonstrated by the occurrence of correlative STs in cores CALA 04, 05 and CQ14_02 (Figs. 3, 5, 7 and 11). For the AD 1908 earthquake we know that at least a third canyon system was activated as shown by the third cable break which occurred in a slope terrace (N. 4 in Fig. 1).

We interpret that ST3 was emplaced during the AD $1169 \mathrm{Mw}=$ 6.41 earthquake, which had lower energy than the earthquakes generating ST2 and ST1 (Table 1). The thickness of ST3 is similar to that of ST2 in core CQ14_02, which implies that the canyon system N. 1 and 2 were both active during the AD 1169 earthquake.

ST1, ST2 and ST3 are present also in cores CALA 06 and 07, which are located in other confined basins of the accretionary wedge and were used only for turbidite correlation (Figs. 1,2 and 11).

Our results, similar to other studies imply that location of coring sites is a key point and has to be considered carefully (Goldfinger et al., 2012; Sumner et al., 2013; Talling, 2014; Goldfinger et al., 2014; Patton et al., 2015). Not all earthquakes trigger widespread slope failure, turbidite distribution may vary in different types of turbidite systems, and the threshold strength for an earthquake to generate an ST will vary in dif ferent geologic settings and thus the ST record may be incomplete in 


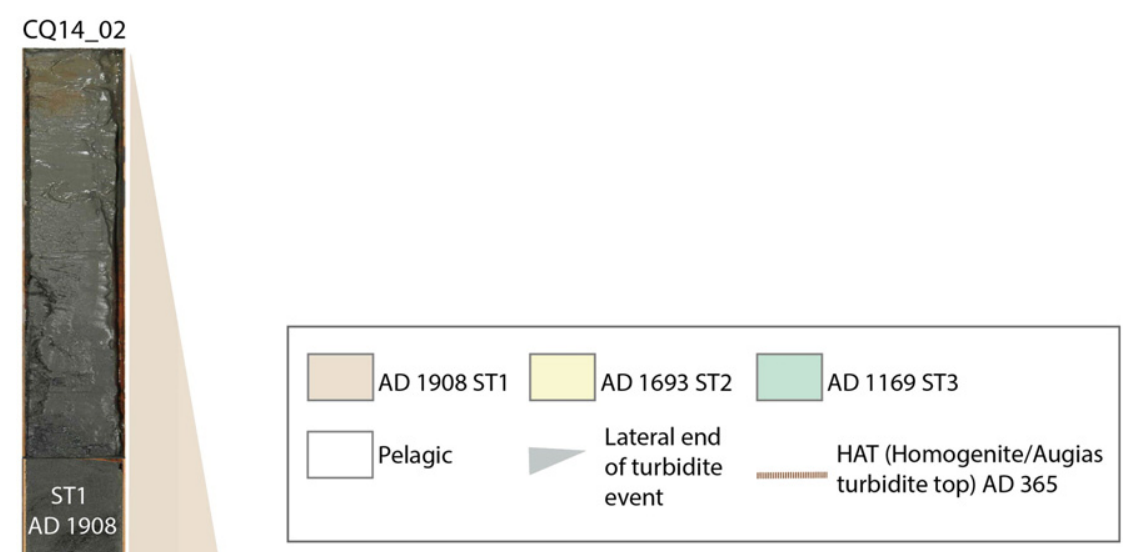

CALA 04

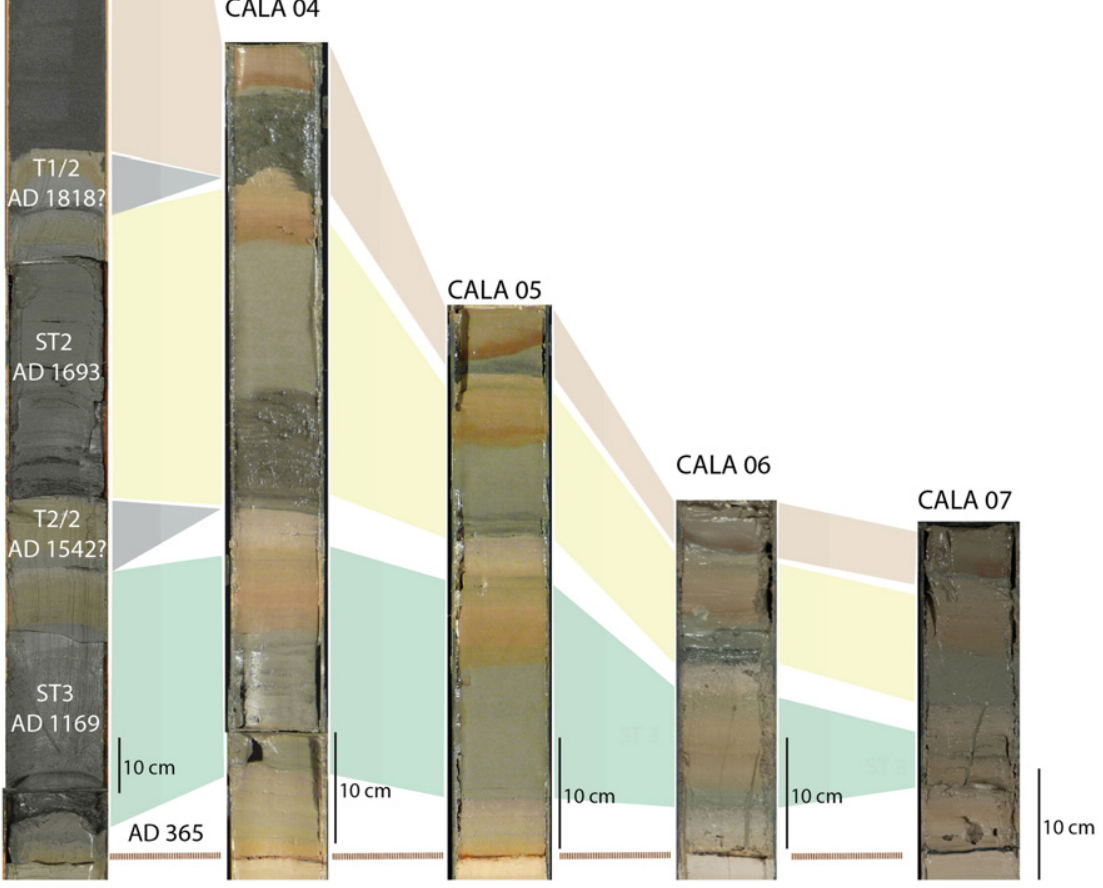

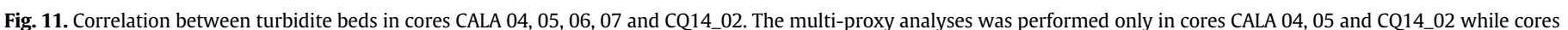

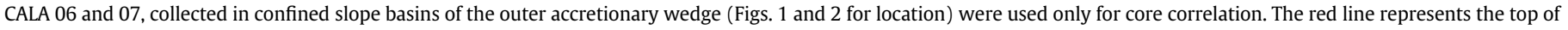

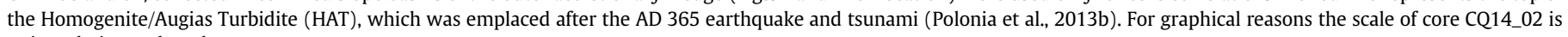
twice relative to the other cores.

some locations (Nelson et al., 2000; Strasser et al., 2013; Nelson et al., 2014; Talling, 2014).

Core CALA 05 which is located in a deep slope confined basin with out a direct canyon pathway has thinner STs than CALA 04, which is located in the abyssal plain with direct canyon access. Core CQ14_02, which was collected in a confined slope basin fed directly by the canyon system N. 2 exhibits thicker ST1, ST2 and ST3 than in cores CALA 04 and 05 (Figs. 1, 3, 5 and 7). In addition, two new turbidites, T1/2 and T2/2 (Figs. 7 and 8), not observed before, were deposited during the last 2000 years in this basin. Stratigraphically, T1/2 was deposited between the time of the AD 1908 and AD 1693 earthquakes (Fig. 7). If T1/2 was not generated by other processes, but was generated by an earthquake, ${ }^{14} \mathrm{C}$ ages on available pelagic sediments and age modelling suggest that ${ }^{\text {it }}$ may be correlated with the AD 1818 or AD 1783 earthquakes (Figs. 9 and 10; Table 1; SM1). Location and magnitude of the two earthquakes (i.e. the $\mathrm{Mw}=5.94 \mathrm{AD} 1783 / 2$ and $\mathrm{Mw}=6.23 \mathrm{AD} 1818$ ) suggest that the most likely source for turbidite T1/2 is the AD 1818 earthquake, be cause it is stronger and it occurred close to Catania, in the Ionian Sea region (Fig. 1; Table 1).
T2/2 was deposited between the AD 1693 and AD 1169 STs, and, if it is seismically triggered, ${ }^{14} \mathrm{C}$ ages on pelagic sediments below T2/2 sug gest that it is correlated with the Mw $=6.62$ Siracusa AD 1542 earth quake (Figs. 7, 9 and 10; Table 1; SM1).

Our Ionian Sea research and studies elsewhere in Japan and Cascadia Basin suggest that there are earthquake magnitude thresholds required to generate STs, but thresholds vary in different basin settings depend ing on rupture depth, earthquake type and distance from the slope to the earthquake rupture (Nakajima and Kanai, 2000; Nelson et al., 2000; Strasser et al., 2013; Van Daele et al., 2013, 2014). The Ionian Sea confined basin setting, like other confined basins, seems to have lower thresholds (Mw 6.2) for ST generation than in unconfined basins like Cascadia and Japan (Mw 7.2) (Nakajima and Kanai, 2000; Nelson et al., 2000; Strasser et al., 2013; Goldfinger et al., 2012). For the Ionian Sea, the lower threshold for earthquake triggering may be related to the pe culiar physiography of this basin with very narrow shelves, steep conti nental slopes, high sedimentation rates and to the presence in the sedimentary section of tephra layers that may act as weak horizons en hancing slope instability (Harders et al., 2010). 
The characteristics of STs in our cores and the core locations, implies that the main sediment input of turbidites ST1, T1/2, T2/2 and ST3 trav elled downslope along canyon systems N. 2 in the central region, which also feeds the confined slope basin of core CQ14_02 (Fig. 1). On the other hand, the relative maximum thickness of turbidite ST2 in core CALA 04 suggests that the direct sediment input from canyon system at the base of the Malta escarpment (i.e. N. 1 in Fig. 1) was the main pathway to the abyssal depths during the $A D$ 1693 earthquake. This is in agreement with the location of the Alfeo Etna fault system, which has been previously described as the likely source for the AD 1693 earthquake (Polonia et al., 2012, 2013a).

\section{Summary of the ST facies}

The Ionian Sea STs are characterized by a basal stacked sand/silt that grades upward into silt homogenites and a clayey silt cap. Colour chang es integrated with sedimentologic, geochemical, mineralogic and mi cropaleontologic data outline four different sediment facies (STa, STb, STc, STd) (Figs. 3, 5, 7 and SM2 to SM4).

The STa basal unit is represented by dark sand/silt grain size sediment that generally exhibits stacked turbidite beds with different grain size units, and geochemical/micropaleontologic composition (Figs. 3, 5 and 7). Turbidite stacking may result from multiple earth quake induced failures, a complex earthquake or both. The greatest number of stacked units per each ST are found in the abyssal plain, while the more protected basin setting of CALA 05 core, contains finer sediment, thinner deposits and a lower number of stacked units (Figs. 3 and 5). The thickest and coarsest grained turbidites occur in the confined basin of the slope terrace directly fed by canyon N. 2 (Figs. 1, 7 and 11).

Unit STb is characterized by homogenous multimodal clayey silt, which shows an overall decrease in $\mathrm{C} / \mathrm{N}$ related to a gradual increase in $\mathrm{N}_{\text {tot }}$; this suggests a more progressive marine input (Figs. 3 to 7). Micropaleontology also suggests a progressively marine input because of the dominance in the benthic assemblages of a wide range of bathymet ric and abyssal foraminifera.

Unit STc, where present, has a dark orange colour and is generally characterized by mm thick white and dark orange lamina whose geochemical, micropaleontologic and compositional characteristics suggest a more marine input (Figs. 4, 6 and 8). The grain size mode of this unit is similar to the pelagic intervals, but the texture grades upward.

The upper light orange STd unit is homogenous and shows at its base new input of coarser material, a slight increase in CT number together with an increase in $\mathrm{Al}, \mathrm{Fe}$ and $\mathrm{Mn}$ at its base (core CALA 05) and local oc currence of inner shelf foraminifera (Figs. 3 to 7). All these proxies are interpreted to represent an increased continental input in the STd unit deposition. An increase in Mn at the STd base (Fig. 5) is very similar to what has been found in tsunamites along the Japanese margin after the 2011 Tohoku earthquake (Arai et al., 2013; Ikehara et al., 2014; Kanamatsu et al., 2014; McHugh et al., 2016). The Mn enriched sedi ments have been interpreted to be the reworking of the redox layer close to the seabed by the tsunami wave (McHugh et al., 2016).

The differences between these two STc and STd units are best expressed in the abyssal plain deposits (Fig. 3). The slope terrace de posits do not always exhibit the laminated dark orange unit, which is present only in turbidites ST1, T1/2 and ST2 (Fig. 7). ST3 in core CQ14_02 does not show any laminated dark orange unit, but this may result from the high degree of bioturbation present in the turbidite tail, which has destroyed all primary structures. T2/2 is different from all STs because it does not show the laminated dark orange STc unit, nor sharp unit boundaries but, rather, gradual transitions (Fig. 8b). T2/ 2 is unique because it is the only deposit that appears to be related to a non tsunamigenic earthquake (i.e. the AD 1542 event) (Figs. 7, 8b and 10).

\section{Sedimentary processes for STa, b, c, d facies}

The basal multiple coarse STa sub units are attributed to synchronous earthquake triggering of multiple sediment failures and turbidity currents that have travelled downslope through different canyons across the margin and/or to multiple seismic events such as the case of the AD 1693 double earthquakes (Fig. 12b, c; Table 1). Slope mor phology provides the first clue that the STa units consist of ST stacked sub units because two upper slope canyons converge to directly feed the westernmost canyon (N1) that feeds the CALA 04 and 05 sites of de position. Synchronously triggered turbidity currents that converge below multiple tributary canyon confluences are a typical setting for de positing stacked ST (e.g. Nelson et al., 2012, 2014; Gutiérrez Pastor et al., 2013). Stacked STs were first described from the confined basins of Swiss lakes, where historic earthquakes triggered coeval landslides and turbidity currents around the basin slopes that than deposited STs on the basin floor (Strasser et al., 2007). This process also may have con tributed to the STs found in the Ionian slope basin terrace (Figs. 1 and 7) and is another process that can create amalgamated beds (Nelson et al., 2012).

The repeated coarser texture and sedimentary structures indicate that the multiple STa sand/silt sub units of ST1, ST2, and ST3 are deposited from different slope failures and turbidity currents. The multiple sand or sandy silt sub units, which exhibit separate textural gradation and repeated parts of Bouma $\mathrm{Tb}, \mathrm{Tc}$, and Td sequences help define the different STa stacks (Figs. 3 to 7 and 12) (SM2 to SM4). Often the sand stacks are finer grained in upper sub units, but sometimes they are coarser such as in ST3a1 (Figs. 3 and 5). Variable graded STa sub units with different Bouma sequences and/or flow directions have been ob served below tributary canyon and channel confluences in both open and confined basins (e.g. Nelson et al., 2012, 2014; Gutiérrez Pastor et al., 2013; Van Daele et al., 2014).

The varying composition and flow directions of the different STa units is the key evidence to prove that the Ionian stacked ST result from different sediment sources that were synchronously triggered by earthquakes. For example, retrograde slope failures could possibly create multiple sand sub units and sequences of sedimentary structures. However, different compositions and sources of each subunit stack confirm that synchronous turbidity currents were triggered by an earth quake (Fig. 12). In the Ionian STs, the $\mathrm{C} / \mathrm{N}$ ratios show that one basal stack can have a more marine source while the overlying stack has a more continental source such as in ST3a (Fig. 3). The foraminifera as semblages also show a difference in the two stacks of ST3a, where the lower sub unit ST1a1 lacks inner shelf species and the upper sub unit ST1a2 includes inner shelf species. In ST2a, the higher content of $\mathrm{Zr}$ and $\mathrm{Ba}$ in the lower stack ST2a1 compared to the upper stack ST2a2, shows an example of different geochemical sources for the two stacks (Fig. 5). Mineralogy also can differ for separate sub unit stacks (SM2 to SM4).

The textural and compositional differences both support the interpretation that the Mw $67+$ historic earthquakes in the Calabrian Arc region generate stacked STs (Fig. 10). These results agree with previous work in Japan (Nakajima and Kanai, 2000), off California (Goldfinger et al., 2007) and Chile (Van Daele et al., 2014) where sedimentary struc tures and composition verify the origin of seismic generated stacked turbidites from similar magnitude earthquakes. It also supports the in terpretation that these lower magnitude earthquakes ( $\mathrm{Mw} 6$ to 8 ) are characterized by stacked turbidites below confluences of multiple can yon sources (Nelson et al., 2012, 2014). In contrast, the shaking of the world's strongest subduction zone earthquakes (Mw 9 with nearly $32 \times$ more energy than Mw 8) cause STs with multiple basal sand units that appear to result mainly from the shaking signature of the great earthquakes rather than stacking below confluences (Nelson et al., 2012, 2014; Gutiérrez Pastor et al., 2013).

The STb unit is a common homogenite mud deposit that is found above the coarser grained basal sandy part of STs (Nelson et al., 

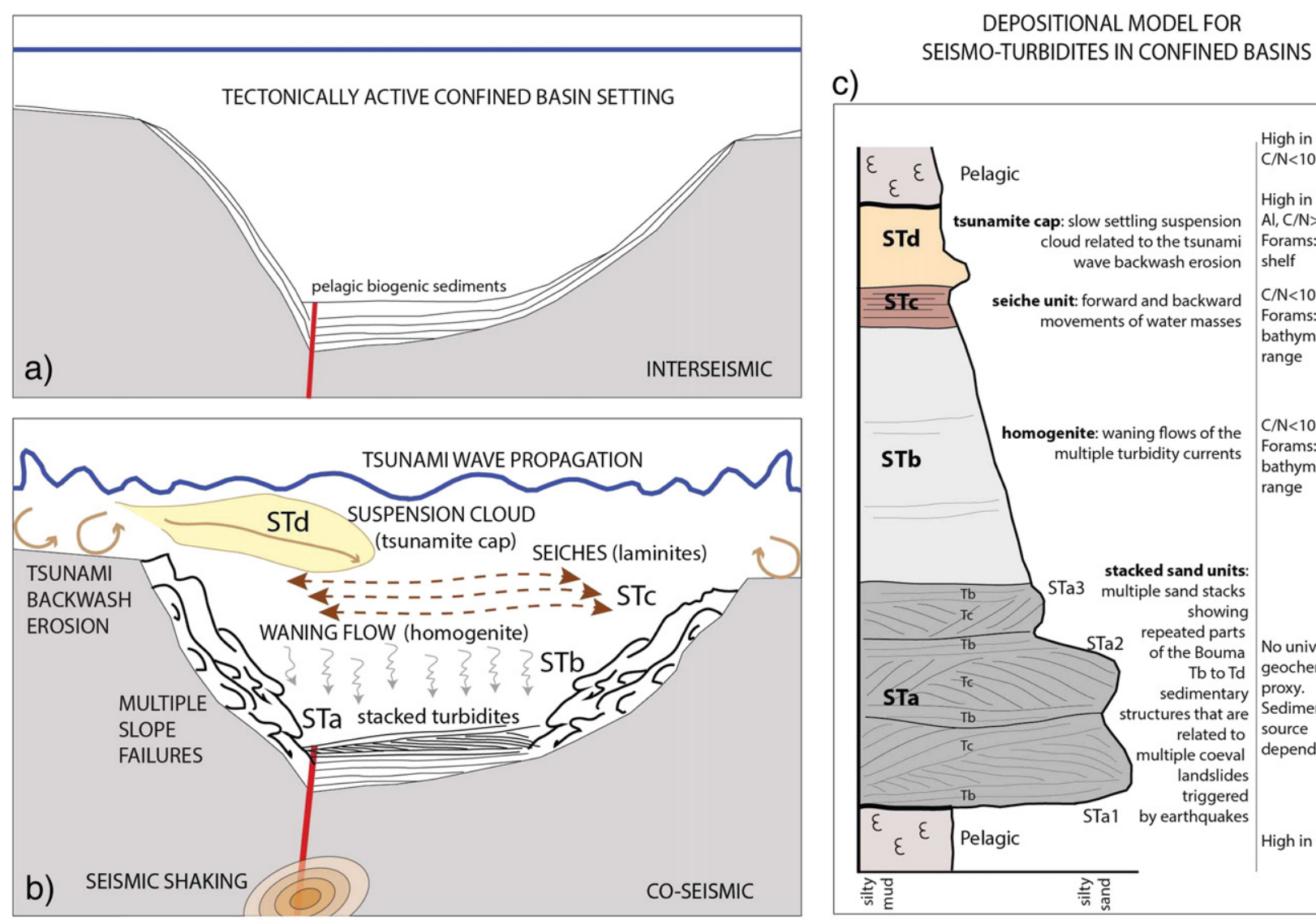

c)

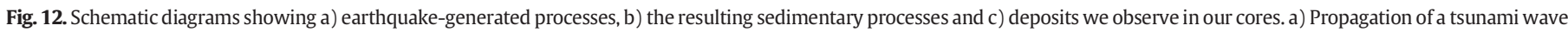

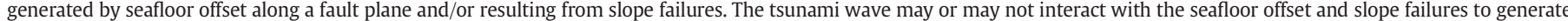

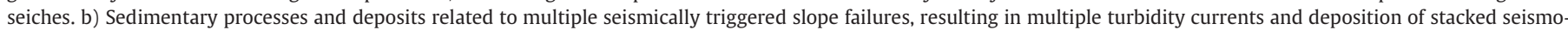

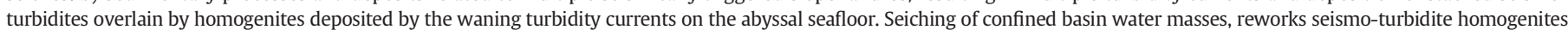

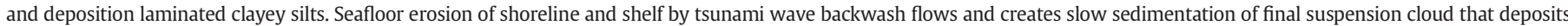

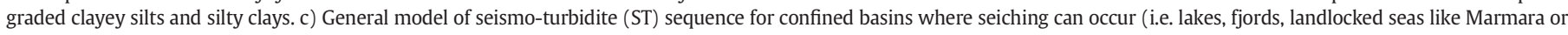

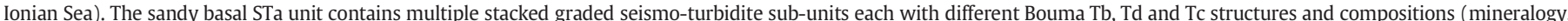

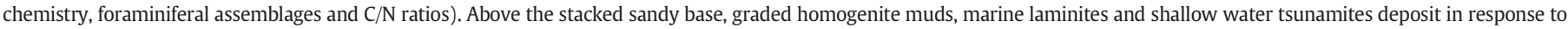
waning of the turbidity currents, seiching processes and tsunami backwash.

2014). This clayey silt turbidite tail, which gradually fines upward with an increasing clay content, is characteristic of STs in confined basins such as the Ionian Sea (Fig. 1). Similar homogenite ST deposits have been described previously in the Marmara Sea, Antilles Basin, Aysén Fjord and many Swiss lakes (Beck et al., 2007, 2012; Beck, 2009; Çagatay et al., 2012; Van Daele et al., 2013; Strasser et al., 2007; Hilbe and Anselmetti, 2015). Because of the synchronous earthquake trigger ing of multiple turbidity currents, and the basin confinement that traps the suspension cloud of these coeval turbidity currents, these waning turbidite tail homogenite muds deposit over the basal coarser deposits of an ST (Figs. 3, 5, 7 and 12). Several months after the 2010 Haiti earth quake, a $600 \mathrm{~m}$ thick suspension cloud was found in the Puerto Rican Trench (McHugh et al., 2011). Similar suspension cloud deposits appar ently have created these homogenite deposits in the Ionian and other confined basins.

The STc unit is characterized by mm thick white and dark laminae, has minimal textural grading and contains a more marine composition of $\mathrm{C} / \mathrm{N}$ ratios and foraminiferal assemblages (Figs. 3, 4, 5, $6,7$ and $8 \mathrm{a})$. Based on marine composition and particularly the lamina, we interpret that the dark orange STc unit is related to basin wide seiching in the Io nian Sea (Fig. 12a, b). These forward and backwards movements of the water mass can be related to the earthquake secondary surface waves or tsunamis or a combination of both (Fig. 12). The seiching process can re suspend sediment on the slope, which then flows as a dilute turbidity current, or it can trigger wave induced bottom currents, which then interact with the seafloor sediment. We have not been able to obtain enough detailed information on the STc units to distinguish which one of these sediment transport mechanism produce the laminae. However, we believe that seiching bottom currents reworking sediment is the most likely process because there is no grading and multiple lamina are present in the STc unit. Fine scale laminations are also formed by the migration of diagenetic fronts. However, our $11585 / 559807$ multi proxy analysis and the integrated interpretation of organic carbon data, foraminiferal assemblages, geochemistry and sedimentology suggest that the sharp base of this unit represents a discontinuity in sedimentation and the be ginning of a new cycle in the sedimentation related to the seiching processes.

Both earthquake surface waves and the surge of tsunami waves may be involved in the creation of basin seiches. Surface waves from the world's strongest Mw 9 earthquakes are known to cause entire ocean basins to seiche. For example, the tide gauge time series after the 2004 Sumatra tsunami showed high frequency oscillations with periods rang ing from minutes to hours, which persisted for several days after the tsunami (Pattiaratchi and Wijeratne, 2009). These oscillations mainly consisted of two types: (1) waves that comprise the tsunami and are usually identified in tide gauge records during the first few hours of a tsunami, and (2) oscillations that are set up by the tsunami but whose periods are governed by the local topography. These oscillations may continue for several days after the tsunami's impact, with energy in a particular period enhanced because of the tsunami. After the 2004 
tsunami, these oscillations were observed in Western Australia, which shows that these processes affect entire ocean basins as well as confined basins. For example in the enclosed basin of the Gulf of Mexico, newspa pers reported that after the Mw 9.2 1964 Alaskan earthquake, the seiches from the earthquake caused boats to break away from their moorings. On the other hand, Mw 6 earthquakes affecting Swiss lakes, may be too weak for earthquake surface waves to cause seiches, but large tsunami events, most likely related to earthquake subaqueous sed iment failures in the lakes have resulted in water level oscillations that lasted for eight days (Hilbe and Anselmetti, 2014). Seiche deposits have been reported from STs of other confined basins (McHugh et al., 2006, 2011; Beck et al., 2007; Beck, 2009; Çagatay et al., 2012; Hilbe and Anselmetti, 2015).

For the historic AD 1908 earthquake, there is evidence of seiching in the Ionian Sea after the earthquake and related tsunami. Baratta (1910) describes eyewitness reports of a very rough sea, which lasted one day or more after the initial tsunami wave. These post tsunami water mass movements are described as decreasing oscillations with a period of $1214 \mathrm{~min}$ and amplitudes of $56 \mathrm{~m}$ lasting for 5 $\mathrm{h}$ after the main tsunami wave. This evidence supports our inter pretation that seiching oscillations in the confined Messina Straits area appear to be responsible for the deposition of unit STc in the AD 1908, AD 1818, AD 1693 and AD 1169 earthquake and tsunami deposits.

The two dark orange and light orange STc and STd units are characterized by significant differences in sedimentary structures, textural grading and composition. The STd unit is homogeneous but graded, lacks sedimentary structures, has a more continental origin of $\mathrm{C} / \mathrm{N}$ ra tios, and often includes inner shelf foraminiferal species (Figs. 3 to 7). Because of the grading and more continental composition, we interpret that the light orange STd unit, is a tsunamite cap created by tsunami shoreline and shelf erosion and backwash return turbidity currents, which deposit the final sediment in the Ionian Sea STs (Fig. 12). The greatest travel distance and slow settling of tsunami sediment results in a graded texture, the finest grain size, and more continental material from the shallow water backwash (Figs. 3 to 7). The Mn enriched layer at the base of light orange Tc units in core CALA 05 is another important observation, because it may result from the shallow veneer of the most recent sediment (close to the redox front) that was entrained by the tsunami wave backwash (Figs. 5 and 12b). Compared to confined basin settings, neither tsunamite caps nor seiche deposits have yet been observed in 100s of STs from the unconfined basin settings of the Cascadia and northern California margins (Nelson et al., 2000; Goldfinger et al., 2007, 2012).

Although there is significant variation in the ST1, ST2, and ST3 a and b parts of the STs at different locations in the Ionian Sea (Fig. 10), the STc and STd units have more or less the same thickness at all locations. For example, although units STa and STb in core CALA 07 are thinner rela tive to core CALA 04 because of the more confined setting, the STc and STd units have a comparable thickness (Fig. 11). The consistent thick ness of STc and STd indicates that their deposition is related to regional basin wide depositional processes such as seiches and tsunamis would cause (Fig. 12).

In contrast to the generally consistent thickness of the STc and STd units, the varying thickness, stacking patterns, textures and compositions of the STa and STb units in different depositional settings, indicate that STa and STb are generated by local in contrast to basin wide pro cesses (Fig. 12). The direct canyon access of the CALA 04 site results in the clearest distinction of the STa and STb units, whereas the confined setting of CALA 05 results in less developed units (Figs. 3 and 5 ). The di rect access of a canyon to a confined proximal terrace results in thickest STa and STb units and again shows that they are deposited from local failure sources (Figs. 7). However, in any of these depositional settings, the variation of texture and composition of the STa stacked turbidites shows that they are derived from multiple local slope failures triggered by the earthquakes.
Assuming that the $\mathrm{T} 2 / 2$ turbidite is generated by the non tsunamigenic AD 1542 earthquake, T2/2 has a thickness comparable to the T1/2 turbidite despite the 400 year time interval between AD 1169 and 1542 earthquakes and the 100 year interval prior to deposi tion of T1/2 (Figs. 7 and 10). This thickness relationship suggests that tsunamigenic earthquakes (i.e. ST1, T1/2, ST2, ST3) may re suspend and transport larger amounts of sediment than non tsunamigenic earthquakes (i.e. $\mathrm{T} 2 / 2$ ). Most important, $\mathrm{T} 2 / 2$, which is the only turbi- dite apparently not associated with a tsunami, is different from all other STs because it does not contain the Tc or Td units and consists of only STa and STb units (Fig. $8 \mathrm{~b})$. This observation suggests that the STs generation by non tsunamigenic earthquakes in confined basins lack the Tc and Td units that are associated with tsunamigenic earthquakes.

\section{The AD 1908 (Mw = 7.2) Messina earthquake and tsunami}

Because the single AD 1908 Messina earthquake resulted in ST1a turbidite stacks from multiple slope failures, this observation provides information to understand the highly debated origin for the 1908 tsunamis (seismically or landslide triggered) (e.g. Fig. 4; Table 1). The AD 1908 earthquake rupture, which is reported to be on the order of $1 \mathrm{~m}$ (Loperfido, 1909; Valensise and Pantosti, 1982), can create a runup of the same amplitude or a bit more (Okal and Synolakis, 2004). It follows that a significant part of the $11 \mathrm{~m} 1908$ tsunami runup must have been triggered by landslides, which is in agreement with the observation of three submarine cables breaks downslope along the margin (Ryan and Heezen, 1965) and models that include a composite source (e.g. earth quake and landslide) (Tinti et al., 2008; Tappin, 2008; Favalli et al., 2009). The location of slope failures, however, is highly debated (see Billi et al., 2009 and references therein). The different texture, sedimentary structures and composition of multiple ST1a stacks that we observe suggests that more than one slope failure occurred after the earthquake (Figs. 3 to 7). Our study thus provides information to unravel likely trav el paths, sources and failure emplacement mechanisms, to help under stand 1908 tsunami generation.

Turbidite ST1a in CALA 04 consists of three different stacked turbidites, which show low $\mathrm{N}_{\text {tot }}$ and $\mathrm{C} / \mathrm{N}>10$ and suggest a more continental input (Figs. 3 and 4a). Thus, we interpret that seismic shaking triggered at least three slope failures, even though we cannot exclude more than three. The first failure occurred in a deeper environment (no inner shelf foraminifera are present) and was followed by two additional slope fail ures with sources closer to the coast, which have entrained material from shallow water and inner shelf foraminifera. Consequently, these slope failures can be considered the likely source, together with seismic shaking, for the generation of the AD 1908 tsunami, which agrees with the study of Billi et al. (2008).

The ST1a characteristics at other locations provide further information on the dynamics of the AD 1908 slope failures (Fig. 1). Multiple canyon systems fed by the event (i.e. canyon N. 1 in cores CALA 04 and 05; canyon N. 2 in core CQ14 02; canyon N. 4 responsible for cable breaks), show that more than one landslide was triggered by the earthquake. The presence of volcanic minerals in the basal ST1a1 subunit of core CQ14_02 suggests that the first slope failure occurred in the region be tween Mt. Etna and the Messina Strait (SM4). This area is connected to the canyons N. 1 and 2 (Fig. 1), however, ST1 thickness up to $1.35 \mathrm{~m}$ in core CQ14_02 suggest that the main contribute is from canyon N.2.

\section{The composite AD $1693 \mathrm{Mw}=7.4$ earthquake}

The AD 1693 seismic sequence started on January 9 with an earth quake of $\mathrm{Mw}=6.21$ which was followed by the strongest earthquake of Mw $=7.41$ two days after (Table 1 ). Consequently, we need to con sider if it is likely that the stacked turbidite ST2 in our cores could repre sent the final product of these two closely spaced earthquakes. The magnitude Mw $=6.21$ of the first earthquake $(1693 / 1$ in Table $1)$ is 
weaker than the AD 1818 and AD 1169 earthquakes, which apparently triggered the T1/2 and ST3. These STs have a lower sand content (25\%and $15 \%$ respectively) than other STs (up to $85 \%$ of sand), which sug gests that earthquake magnitudes in the range of Mw 6 are too low to trigger turbidity currents depositing thick sand stacks on the abyssal plain (Figs. 3, 5 and 7). Because ST2a has a sand content up to $70 \%$, it seems most likely that ST2a deposits are related to multiple slope fail ures triggered by the second stronger Mw 7.41 earthquake, similar to the ST1a deposits (Figs. 3 and 7). The relative maximum thickness of ST2 in core CALA 04 suggests that sediment input for ST2 was from can yon system at the base of the Malta escarpment (i.e. N. 1 in Fig. 1). This canyon location coincides with the location of Alfeo Etna fault system (Polonia et al., 2016b), which previously has been described as the likely source for the AD 1693 earthquake (Polonia et al., 2012, 2013a).

\section{Conclusions}

Five turbidites deposited in the Ionian Sea during the last millennia have been analyzed to determine the seismic shaking and tsunami wave erosion processes that generate seismo turbidites (ST). Using radiocarbon and chronostratigraphic age models, the thickest turbidites are correlated with the $\mathrm{AD}$ 1908 Messina, AD 1693 Catania, and AD 1169 Eastern Sicily earthquakes. Two newly described turbidites that are only present in a perched slope basin appear to be seismically trig gered by the AD 1818 and AD 1543 earthquakes.

Textural, micropaleontologic, geochemical and mineralogic analyses show that the STs have cyclic ordered sediment units (STa, STb, STc and STd) marked by different colours. The basal black STa stacked turbidite unit consists of sandy sub units, with distinct composition related to different sediment failure sources triggered synchronously by earth quakes. The second clayey silt STb homogenite mud unit exhibits de- creased $\mathrm{C} / \mathrm{N}$ ratios, which indicates a more marine provenance. This unit is related to the re suspension of the finer grained and deeper water sediment by the multiple turbidity currents that deposit both the STa basal sand stacks and STb turbidite tail mud units. The dark or ange and laminated STc unit shows more marine input and a lack of tex tural grading. We attribute this unit to water mass seiching resulting from a combination of earthquake shaking, sediment failures, and per- haps tsunami wave interaction in the confined Ionian basin setting. The STd upper unit is fining upward mud with coarser sediment at the base, as well as more abundant inner shelf foraminifera tests, which is not observed in the underlying STc unit. All these proxies are interpreted to indicate a more continental and shallow water input sug gesting that unit STd is related to the slow settling of fine sediment re suspended by tsunami backwash.

Based on these observations and taking into consideration the confined setting of the Ionian Sea, we propose a conceptual depositional model for the development of tsunamigenic earthquake triggered seismo turbidites in a confined basin. This model illustrates the deposition of stacked turbidites, homogenites, laminites and tsunamites as a response to the complex succession of sedimentary processes following seismic shaking: multiple slope failures, waning flows of the turbidity currents, water mass seiching and tsunami backwash erosion. These confined basin STs contrast with unconfined basin STs that lack the STc seiche unit and have poor or no development of the STd tsunamite cap unit created by basin confinement.

The Messina AD 1908 and Catania AD 1693 STs provide two case his tories with the most information on the triggering seismic events. The AD 1908 ST1 consists of three different stacked turbidite STaunits, sug gesting that seismic shaking triggered at least three slope failures. The first failure occurred in a deeper environment close to Mt. Etna because of more marine geochemical proxies, the absence of inner shelf forami nifera and the presence of volcanic minerals. This deeper slope failure was followed by two additional shallower failures, located in Southern Calabria and NE Sicily. These sediment failures can be considered the likely cause, together with coseismic seafloor displacement, for the gen eration of the AD 1908 tsunami.

The AD 1693 ST2 contains two distinct stacked beds that could be linked to multiple slope failures or to the sequence of two earthquakes two days apart. However, we interpret that the magnitude $(\mathrm{Mw}=6.21)$ of the first earthquake, which occurred on January 9, was not strong enough to trigger a turbidity current traversing to the abyssal plain. Instead, we suggest that the stacked ST2a is the result of multiple slope failures caused by the strongest historic earthquake ( $\mathrm{Mw} 7.4)$ in the Calabrian Arc region.

\section{Acknowledgements}

We thank the CALAMARE scientific party, Captain Lubrano, Urania shipboard and SOPROMAR parties for their contribution in core collec tion during the Urania cruises. We also acknowledge the CIESM/Ifremer Medimap group (Loubrieu B., Mascle J. et al., 2008) for providing us with the multibeam grid of the study area. We thank G. Bortoluzzi, A. Gallerani, E. Dal Passo and A. Ricchi, for logistics with core handling. We are grateful to $\mathrm{C}$. Gelati and $\mathrm{M}$. Imbriani, radiologists at Ospedale Maggiore in Bologna, for CT scan acquisition and to F. Ricci Lucchi and A. Billi for fruitful discussions. L. Langone and F. Savelli are acknowl edged for TOC analysis at ISMAR (Institute of Marine Sciences). Grain size for core CQ14_02 was analyzed at University of Trieste while cores CALA 04 and 05 were analyzed at Universitat de Barcelona with the help of R. G. Lucchi. SEM/EDS analyses were carried out at Dipartimento di Scienze Biologiche, Geologiche e Ambientali, University of Bologna. This work has been supported by MIUR PRIN, 201011 (Pro ject: Active and recent geodynamics of Calabrian Arc and accretionary complex in the Ionian Sea, Prot 20103KTT94_002) and has benefited from funding provided by the CNR for the R/V Urania shiptime (CALAMARE 08 and CALAQUAKE 14). The Editors Michele Rebesco and Peter Talling, Jasper Moernaut, David Piper and Mike Underwood are greatly thanked for their detailed and helpful reviews, which have significantly improved our paper. ISMAR paper N. 1886.

\section{Appendix A. Supplementary data}

Supplementary data to this article can be found online at http://dx. doi.org/10.1016/j.margeo.2016.05.010.

\section{References}

Adams, J., 1990. Paleoseismicity of the Cascadia subduction zone: evidence from turbidites off the Oregon-Washington margin. Tectonics 9, 569-583. http://dx.doi.org/ 10.1029/TC009i004p00569.

AGIP, 1982. Foraminiferi Padani (Terziario e Quaternario). AGIP, Milan, Italy.

Arai, K., Naruse, H., Miura, R., Kawamura, K., Hino, R., Ito, Y., Inazu, D., Yokokawa, M., Izumi, N., Murayama, M., Kasaya, T., 2013. Tsunami-generated turbidity current of the 2011 Tohoku-Oki earthquake. Geology 41, 1195-1198.

Banner, F.T., Blow, W.H., 1960. Some primary types of species belonging to the superfamily Globigerinaceae (Contributions from the Cushman Foundation) For. Res. 11, 1-41

Baratta, M., 1910. La catastrofe sismica calabro-messinese (28 Dicembre 1908). Relazione alla Società Geografica Italiana, Roma, p. XV (2 voll. (text and atlas)). (426, OCLC 38646170; https://www.worldcat.org/title/terremoto-calabro-siculo-del-28dicembre-1908-messina/oclc/38646170).

Beck, C., 2009. Late Quaternary lacustrine paleo-seismic archives in north-western Alps: examples of earthquake-origin assessment of sedimentary disturbances. Earth Sci. Rev. 96, 327-344.

Beck, C., Mercier de Lépinay, B., Schneider, J.-L., Cremer, M., Çağatay, N., Wendenbaum, E., Boutareaud, S., Ménot, G., Schmidt, S., Weber, O., Eris, K., Armijo, R., Meyer, B., Pondard, N., Gutscher, M.-A., the MARMACORE Cruise Party, Turon, J.-L., Labeyrie, L., Cortijo, E., Gallet, Y., Bouquerel, H., Gorur, N., Gervais, A., Castera, M.-H., Londeix, L., de Rességuier, A., Jaouen, A., 2007. Late Quaternary co-seismic sedimentation in the Sea of Marmara's deep basins. In: Bourrouilh-Le Jan, F., Beck, C., Gorsline, D.(Eds.), Sedimentary Records of Catastrophic Events. Sedimentary Geology Special Is-sues vol. 199, pp. 65-89.

Beck, C., Reyss, J.-L., Leclerc, F., Moreno, E., Feuillet, N., Barrier, L., Beauducel, F., Boudon, G. Clément, V., Deplus, C., Gallou, N., Lebrun, J.-F., Le Friant, A., Nercessian, A., Paterne, M., Pichot, T., Vidal, C., 2012. Identification of deep subaqueous coseismic scarps through specific coeval sedimentation in Lesser Antilles: implication for seismic haz-ard. Nat. Hazards Earth Syst. Sci. 12, 1755-1767. http://dx.doi.org/10.5194/ nhess-12-1755-2012. 
Billi, A., Funiciello, R., Minelli, L., Faccenna, C., Neri, G., Orecchio, B., Presti, D., 2008. On the cause of the 1908 Messina tsunami, southern Italy. Geophys. Res. Lett. 35 (6), L06301. http://dx.doi.org/10.1029/2008GL033251.

Billi, A., Funiciello, R., Minelli, L., Faccenna, C., Neri, G., Orecchio, B., Presti, D., 2009. Reply to comment by Andrea Argnani et al. on "On the cause of the 1908 Messina tsunami, southern Italy". Geophys. Res. Lett. 36 (13), L13308. http:// dx.doi.org/10.1029/2009GL037499.

Blanc-Vernet, L., 1969. Contribution à l'étude des foraminifères de Méditerranée. Travaux de la Station Marine d'Endoume, Marseille, France.

Boschi, E., Guidoboni, E., Ferrari, G., Valensise, G., Gasperini, P., 1997. Catalogo dei forti terremoti in Italia dal 461 A.C. al 1990. INGV-SGA, Bologna, p. 644

Boschi, E., Guidoboni, E., Ferrari, G., Mariotti, D., Valensise, G., Gasperini, P., 2000. Cata-

logue of strong Italian earthquakes from 461 B.C. to 1997. Ann. Geofis. 43, 609-868. Bronk 42-60.

Ramsey, C., 2008. Deposition models for chronological records. Quat. Sci. Rev. 27,

Bronk Ramsey, C., Lee, S., 2013. Recent and planned developments of the program OxCal. Radiocarbon 55, 720-730.

Cagatay, M.N., Erel, L., Bellucci, L.G., Polonia, A., Gasperini, L., Eris, K., Sancar, Ü., Biltekin, D. Uçarkus, G., Ülgen, U.B., Damci, E., 2012. Sedimentary earthquake records in the Izmit Gulf, Sea of Marmara, Turkey. Sediment. Geol. 282, 347-359. http:// dx.doi.org/10. 1016/j.sedgeo.2012.10.001

Carter, L., Milliman, J.D., Talling, P.J., Gavey, R., Wynn, R.B., 2012. Near-synchronous and delayed initiation of long run-out submarine sediment flows from a recordbreaking river flood, offshore Taiwan. Geophys. Res. Lett. 39, L12603. http:// dx.doi.org/10. 1029/2012GL051172.

Casalbore, D., Chiocci, F.L., Scarascia, M.G., Tommasi, P., Sposato, A., 2011. Flash-flood hyperpycnal flows generating shallow-water landslides at Fiumara mouths in Western Messina Strait (Italy), "Special issue: Seafloor mapping for geohazard assessment”. Mar. Geophys. Res. 32, 257-271. http://dx.doi.org/10.1007/s11001-011-9128-y.

Cita, M.B., Ciampo, G., Ferone, E., Moncharmont Zei, M., Scorziello, R., Taddei Ruggiero, E. 1974. Il Quaternario del Tirreno abissale. Interpretazione stratigrafica e

paleoclimatica del pozzo DSDP 132. Rev. Esp. Micropaleontol. 2, 257-326.

Duliu, O.G., 1999. Computer axial tomography in geosciences: an overview. Earth-Sci. Rev. $48,265-281$

Faccenna, C., Molin, P., Orecchio, B., Olivetti, V., Bellier, O., Funiciello, F., Minelli, L., Piromallo, C., Billi, A., 2011. Topography of the Calabria subduction zone (southern Italy): clues for the origin of Mt. Etna. Tectonics 30, TC1003. http:// dx.doi.org/10. 1029/2010TC002694.

Favalli, M., Boschi, E., Mazzarini, F., Pareschi, M.T., 2009. Seismic and landslide source of the 1908 Straits of Messina tsunami (Sicily, Italy). Geophys. Res. Lett. 36, L16304.

http://dx.doi.org/10.1029/2009GL039135.

Friedman, G.M., Sanders, J.E., 1978. Principles of Sedimentology. John Wiley \& Sons, New York, p. 792.

Gasperini, L., Stanghellini, G., 2009. SeisPrho: an interactive computer program for processing and interpretation of high-resolution seismic reflection profiles. Comput

Geosci. 35 (7), 1497-1507.

Goldfinger, C., Nelson, C.H., Johnson, J.E., 2003a. Deep-water turbidites as Holocene earthquake proxies: the Cascadia Subduction Zone and northern San Andreas Fault sys-tems. Ann. Geophys. 46 (5), 1169-1194.

Goldfinger, C., Morey, A.E., Nelson, C.H., Gutierrez-Pastor, J., Johnson, J.E., et al., 2007. Rupture lengths and temporal history of significant earthquakes on the offshore and north coast segments of the northern San Andreas Fault based on turbidite stratigra-phy. Earth Planet. Sci. Lett. 254, 9-27.

Goldfinger, C., Grijalva, K., Burgmann, K., Morey, A., Johnson, J.E., Nelson, C.H., GutiérrezPastor, J., Karabanov, E., Patton, J., Gracia, E., 2008. Late Holocene rupture of the north-ern San Andreas Fault and possible stress linkage to the Cascadia Subduction Zone. Seismological Society of America, Bulletin 98, 861-899.

Goldfinger, C., Nelson, C.H., Morey, A., Johnson, J.E., Gutierrez-Pastor, J., Eriksson, A.T., Karabanov, E., Patton, J., Gracia, E., Enkin, R., Dallimore, A., Dunhill, G., Vallier, T., 2012. Turbidite event history-methods and implications for Holocene paleoseismicity of the Cascadia subduction zone. U.S. Geological Survey Professional Paper 1661-F, p. 170 (available at http://pubs.usgs.gov/pp/pp1661f/, March 2016)

Goldfinger, C., Patton, J.R., Van Daele, M., Moernaut, J., Nelson, C.H., de Batist, M., Morey, A., 2014. Can turbidites be used to reconstruct a paleo earthquake record for the cen-tral Sumatran margin?: comment. Geology Society of America 42, e344. http:// dx.doi. org/10.1130/G35510C.1.

Gorsline, D.S., De Diego, T., Nava-Sanchez, E.H., 2000. Seismically triggered turbidites in small margin basins: Alfonso Basin, Western Gulf of California and Santa Monica

Basin, California Borderland. Sediment. Geol. 135, 21-35.

Gutiérrez-Pastor, J., Nelson, C.J., Goldfinger, C., Escutia, C., Eriksson, A., Morey, A.E., The Shipboard Scientific Party, 2009. Earthquake control of Holocene turbidite frequency confirmed by hemipelagic sedimentation chronology on the cascadia and northern california active continental margins. In: Kneller, B., Martissen, O.J., McCaffrey, B. (Eds.) SEPM Special Publication 92. Society for Sedimentary Geology, Tulsa Oklahoma, pp. 179-197 (ISBN 978-1-56576-200-8, available online at http://activetectonics.coas. oregonstate.edu/paper_files/Gutierrez-Pastor\%20et\%20al,2009.pdf, March 2016).

Gutiérrez-Pastor, J., Nelson, C.J., Goldfinger, C., Escutia, C., 2013. Sedimentology of seismoturbidites off the Cascadia and northern California active tectonic continental margins, northwest Pacific Ocean. Mar. Geol. 336, 99-119. http://dx.doi.org/10.1016/j. margeo.2012.11.010

Harders, R., Kutterolf, S., Hensen, C., Moerz, T., Brueckmann, W., 2010. Tephra layers: a controlling factor on submarine translational sliding? Geochem. Geophys. Geosyst. 11 (5), Q05S23. http://dx.doi.org/10.1029/2009GC002844.

Hilbe, M., Anselmetti, F.S., 2014. Signatures of slope failures and river-delta collapses in

a perialpine lake (Lake Lucerne, Switzerland). Sedimentology 61 (7), 1883-1907.

http://dx.doi.org/10.1111/sed.12120.
Hilbe, M., Anselmetti, F.S., 2015. Mass movement-induced tsunami hazard on perialpine Lake Lucerne (Switzerland): scenarios and numerical experiments. Pure Appl. Geophys. 172, 545-568. http://dx.doi.org/10.1007/s00024-014-0907-7.

Howarth, J.D., Fitzsimons, S.J., Norris, R.J., Jacobsen, G.E., 2014. Lake sediments record high intensity shaking that provides insight into the location and rupture length of large earthquakes on the Alpine Fault, New Zealand. Earth Planet. Sci. Lett. 403, 340-351.

Ikehara, K., Irino, T., Usami, K., Jenkins, R., Omura, A., Ashi, J., 2014a. Possible submarine tsunami deposits on the outer shelf of Sendai Bay, Japan resulting from the 2011

earthquake and tsunami off the Pacific coast of Tohoku. Mar. Geol. 349, 91. Kanamatsu, T.,

Kanagawa, Y., Ikehara, K., 2014. Paleoseismology along the Japan Trench subduction zone: deep-sea sediment records of earthquakes in Tohoku (invited) AGU Fall Meeting Oral Presentation: T52A-01. San Francisco 15-19 December 2014.

Kastens, K.A., 1984. Earthquakes as a triggering mechanism for debris flows and turbidites on the Calabrian Ridge. Mar. Geol. 55, 13-33.

Kastens, K.A., Cita, M.B., 1981. Tsunami-induced sediment transport in the abyssal Mediterranean Sea. Geol. Soc. Am. Bull. 92, 845-857.

Kennett, J.P., Srinivasan, M.S., 1983. Neogene Planktonic Foraminifera: A Phylogenetic Atlas. Hutchinson Ross Publishing Company, Stroudsburg, Pennsylvania, p. 265.

Köng, E., Zaragosi, S., 2016. Untangling the complex origin of turbidite activity on the Calabrian Arc (Ionian Sea) over the last 60 ka. Mar. Geol. 373, 11-25.

Loperfido, A., 1909. Livellazione geometrica di precisione eseguita dall'IGMI sulla costa orientale della Sicilia, da Messina a Catania, a Gesso ed a Faro Peloro e sulla costa occidentale della Calabria da Gioia Tauro a melito di Porto salvo. per incarico del Ministro dell'Agricoltura, Industria e Commercio, Roma. Relazione alla Commissione Reale Accademia Nazionale dei Lincei 35, pp. 131-155.

Mayer, P.A., 1994. Preservation of elemental and isotopic source identification of sedimentary organic matter. Chem. Geol. 114, 289-302.

McHugh, C.M.G., Seeber, L., Cormier, M.-H., Dutton, J., Çagatay, M.N., Polonia, A., Ryan, W.B.F., Görür, N., 2006. Submarine earthquake geology along the North Anatolian Fault in the Marmara Sea, Turkey: a model for transform basin sedimentation. Earth Planet. Sci. Lett. 248, 661-684. http://dx.doi.org/10.1016/j.epsl.2006.05.038.

McHugh, C.M., Seeber, L., Braudy, N., Cormier, M.-H., Davis, M.B., Diebold, J.B., Dieudonne, N., Douilly, R., Gulick, S.P.S., Hornbach, M.J., Johnson III, H.E., Ryan, K.M., Sorlien, C.C., Steckler, M.S., Symithe, S.J., Templeton, J., 2011. Offshore sedimentary effects of the 12 January 2010 Haiti earthquake. Geology 39, 723-726.

McHugh, C.M. Kanamatsu, T, Seeber, L, Bopp, R, Cormier M-H, Usami, K, 2016. Remobilization of surficial slope sediment triggered by the AD $2011 \mathrm{M}_{\mathrm{w}}$ 9 Tohoku-Oki earthquake and tsunami along the Japan Trench. Geology http://dx.doi.org/10.1130/G37650.1.

Miglietta, M.M., Laviola, S., Malvaldi, A., Conte, D., Levizzani, V., Price, C., 2011. Analysis tropical-like cyclones over the Meditefranean Sea through a combined modeling and satellite approach. Geophys. Res. Lett. 40 (2400-2405), 2013. http:// dx.doi.org/10. 1002/grl.50432.

Moernaut, J., Daele, M.V., Heirman, K., Fontijn, K., Strasser, M., Pino, M., Urrutia, R., De Batist, M. 2014. Lacustrine turbidites as a tool for quantitative earthquake reconstruction: new evidence for a variable rupture mode in south central Chile. J. Geophys. Res. Solid Earth 119, 1607-1633. http://dx.doi.org/10.1002/2013JB010738.

Mulder, T., Mignon, S., Savoye, B., Faugeres, J.-C., 2001. Inversely graded turbidite sequences in the deep Mediterranean. A record of deposits from flood-generated tur-

bidity currents? Geo-Mar. Lett. 21, 86-93.

Mulder, T., Syvitski, J.P.M., Migeon, S., Faugères, J.C., Savoye, B., 2003. Marine hyperpycnal flows: initiation, behavior and related deposits. A review. Mar. Pet. Geol. 20, 861882. http://dx.doi.org/10.1016/j.marpetgeo.2003.01.003.

Murray, J.W., 1991. Ecology and Palaeoecology of Benthic Foraminifera. Longman Scientific and Technical, London.

Murray, J.W., 2006. Ecology and Applications of Benthic Foraminifera. Cambridge University Press, Cambridge.

Mutti, E., Ricci Lucchi, F., Seguret, M., Zanzucchi, G., 1984. Seismoturbidites: a new group of resedimented deposits. Mar. Geol. 55, 103-116.

Nakajima, T., Kanai, Y., 2000. Sedimentary features of seismoturbidites triggered by the 1983 and older historical earthquakes in the eastern margin of the Japan Sea. Sediment. Geol. 135, 1-19.

Nelson, C.H., Goldfinger, C., Johnson, J.E., Dunhill, G., 2000. Variation of modern turbidite systems along the subduction zone margin of Cascadia Basin and implications for turbidite reservoir beds. In: Weimer, P.W., Nelson, C.H., et al. (Eds.), Deep-water Reservoirs of the World. Gulf Coast Section Society of Economic Pa-leontologists and Mineralogists Foundation, 20 Annual Research Conference, pp. 714-717.

Nelson, C.H., Gutiérrez Pastor, J., Goldfinger, C., Escutia, C., 2012. Great earthquakes along the Western United States continental margin: implications for hazards, stratigraphy and turbidite lithology. Nat. Hazards Earth Syst. Sci. 12, 3191-3208 http://dx.doi.org/ 10.5194/nhess-12-3191-2012.

Nelson, C.H., Goldfinger, C., Gutierrez Pastor, J., Damuth, J.E., 2014. Seismo-turbidites: implications for active tectonic margin stratigraphy, lithology and petroleum

reservoirs. Gulf Coast Association of Geological Societies Transactions 64, 589-597.

Okal, E.A., Synolakis, C.E., 2004. Source discriminants for near-field tsunamis. Geophys. J. Int. 158, 899-912.

Omori, F., 1909. Preliminary report on the Messina-Reggio earthquake of December 28 1908. Bulletin of the Imperial Earthquake Investigation Commission 3, 37-46.

Parisi, E., 1981. Distribuzione dei foraminiferi bentonici nelle zone batiali del Tirreno e del Canale di Sicilia. Riv. Ital. Paleontol. Stratigr. 87, 293-328.

Pattiaratchi, C.B., Wijeratne, E.M.S., 2009. Tide gauge observations of 2004-2007 Indian Ocean tsunamis from Sri Lanka and Western Australia. Pure Appl. Geophys. 166, 233-258. http://dx.doi.org/10.1007/s00024-008-0434-5.

Patton, J.R., Goldfinger, C., Morey, A., Romsos, C., Black, B., Djadjadihardja, Y.S., Udrekh, U., 2013. Seismoturbidite record as preserved at core sites at the Cascadia and Sumatra. Nat. Hazards Earth Syst. Sci. 13, 833-867. 
Patton, J.R., Goldfinger, C., Morey, A.E., Ikehara, K., Romsos, C., Stoner, J., Djadjadihardja, Y. Udrekh, Ardhyastut, S., Zulkarnaen Gaffar, E., Vizcaino, A., 2015. A 6600 year earth-quake history in the region of the 2004 Sumatra-Andaman subduction zone earth-quake. Geosphere 11 (9), 1-63. http://dx.doi.org/10.1130/GES01066.1.

Paull, C.K., McGann, M., Sumner, E.J., Barnes, P.M., Lundsten, E.M., Anderson, K., Gwiazda R., Edwards, B., Caress, D.W., 2014. Sub-decadal turbidite frequency during the early Holocene: Eel Fan, offshore northern California. Geology 42 (10), 855-858.

Pino, N.A., Piatanesi, A., Valensise, G., Boschi, E., 2009. The 28 December 1908 Messina Straits earthquake (Mw 7.1): a great earthquake throughout a century of seismology. Seismol. Res. Lett. 80, 243-259.

Piper, D.J.W., Normark, W.R., 2009. Processes that initiate turbidity currents and their influence on turbidites: a marine geology perspective. J. Sediment. Res. 79, 347-362.

Platania, G., 1909. Il maremoto dello Stretto di Messina del 28 Dicembre 1908. Bollettino della Società Sismologica Italiana 13, 369-458.

Polonia, A., Torelli, L., Mussoni, P., Gasperini, L., Artoni, A., Klaeschen, D., 2011. The Calabrian Arc subduction complex in the Ionian Sea: regional architecture, active deforma-tion and seismic hazard. Tectonics 30, TC5018. http:// dx.doi.org/10.1029/2010TC002821.

Polonia, A., Torelli, L., Gasperini, L., Mussoni, P., 2012. Active faults and historical earthquakes in the Ionian Sea. Nat. Hazards Earth Syst. Sci. 12, 2311-2328. http://dx.doi. org/10.5194/nhess-12-2311-2012.

Polonia, A., Panieri, G., Gasperini, L., Gasparotto, G., Bellucci, L.G., Torelli, L., 2013a. Turbidite paleoseismology in the Calabrian Arc subduction complex (Ionian Sea) Geochem. Geophys. Geosyst. 14, 112-140. http://dx.doi.org/10.1029/2012GC004402.

Polonia, A., Bonatti, E., Camerlenghi, A., Lucchi, R.G., Panieri, G., Gasperini, L., 2013b. Mediterranean megaturbidite triggered by the AD 365 Crete earthquake and tsunami. Sci.

Rep. 3, 1285. http://dx.doi.org/10.1038/srep01285.

Polonia, A., Romano, S., Çağatay, M.N., Capotondi, L., Gasparotto, G., Gasperini, L., Panieri, G., Torelli, L., 2015. Is repetitive slumping during sapropel S1 related to paleoearth-quakes? Mar. Geol. 361, 41-52.

Polonia, A., Vaiani, C.S., De Lange, G., 2016a. Did the AD 365 Crete earthquake/tsunami trigger synchronous giant turbidity currents in the Mediterranean Sea? Geology 44,

191-194. http://dx.doi.org/10.1130/G37486.1.

Polonia, A., Torelli, L., Artoni, A., Carlini, M., Faccenna, C., Ferranti, L., Gasperini, L., Govers, R., Klaeschen, D., Monaco, C., Neri, G., Nijholt, N., Orecchio, B., Wortel, R., 2016. The Ionian and Alfeo-Etna fault zones: new segments of an evlving plate boundary in the central Mediterranean Sea? Tectonophysics 675, 69-90. http://dx.doi.org/10.1016/j. tecto.2016.03.016

Pouderoux, H., Proust, J.-N., Lamarche, G., Orpin, A., Neil, H., 2012a. Postglacial (after $18 \mathrm{ka}$ ) deep-sea sedimentation along the Hikurangi subduction margin (New Zealand): characterisation, timing and origin of turbidites. Mar. Geol. 295-298, 51-76. http://dx.doi.org/10.1016/j.margeo.2011.11.002.

Pouderoux, H., Lamarche, G., Proust, J.-N., 2012b. Building an 18 000-year-long paleoearthquake record from detailed deep-sea turbidite characterisation in Poverty Bay, New Zealand. Nat. Hazards Earth Syst. Sci. 12, 2077-2101. http:// dx.doi.org/10. 5194/nhess-12-2077-2012.

Puig, P., Ogston, A.S., Mullenbach, B.L., Nittrouer, C.A., Parsons, J.D., Sternberg, R.W., 2004 Storm-induced sediment gravity flows at the head of the Eel submarine canyon, northern California margin. J. Geophys. Res. 109, C03019. http://dx.doi.org/10.1029/ 2003JC001918.

Rasmussen, T.L., 2005. Systematic paleontology and ecology of benthic foraminifera from the Plio-Pleistocene Kallithea Bay Section, Rhodes, Greece. In: Rasmussen, T.L. Hastrup, A., Thomsen, E. (Eds.), Lagoon to Deep-water Foraminifera and Ostracods From the Plio-Pleistocene Kallithea Bay Section, Rhodes, GreeceSpecial Publication 39. Cushman Foundation, Fredericksburg, Virginia, pp. 53-157.

Ridente, D., Martorelli, E., Bosman, A., Chiocci, F.L., 2014. High-resolution morpho-bathymetric imaging of the Messina Strait (Southern Italy). New insights on the 1908 earthquake and tsunami. Geomorphology 208, 149-159.

Rothwell, R.G., Thomson, J., Kähler, G., 1998. Low-sea-level emplacement of a very large Late Pleistocene 'megaturbidite' in the western Mediterranean Sea. Nature 392, 377-380. http://dx.doi.org/10.1038/32871.
Rovida, A. Camassi, R., Gasperini, P. Stucchi, M. 2011. CPTI11, la versione 2011 del Catalogo Parametrico dei Terremoti Italiani. Istituto Nazionale di Geofisica Vulcanologia, Milano, Bologna http://dx.doi.org/10.6092/INGV.IT-CPTI11 (available at: http://emidius.mi.ingv.it/CPTI, April 2016)

Ryan, W.B.F., Heezen, B.C., 1965. Ionian Sea submarine canyons and the 1908 Messina turbidity current. Geol. Soc. Am. Bull. 76, 915-932

Shanmugam, G., 2011. Process-sedimentological challenges in distinguishing paleo-tsunami deposits. Nat. Hazards 63, 5-30. http://dx.doi.org/10.1007/s11069-011-9766-z. Shiki, T., Cita, M.B., 2008. Tunami-related sedimentary proprierties of Mediterranean Homogenites as an Example of Deep-Sea Tsunamiite (reference in chapter 13 in edited book) TSUNAMIITES: Features and Implication. Elsevier Eds., pp. 203-215.

Shiki, T., Kumon, F., Inouchi, Y., Kontani, Y., Sakamoto, T., Tateishi, M., Matsubara, H., Fukuyama, K., 2000. Sedimentary features of the seismo-turbidites, Lake Biwa Japan. Sediment. Geol. 135, 37-50. http://dx.doi.org/10.1016 S0037-0738(00)00061-0.

Stanley, D.J., 1981. Unifites: structurless muds of gravity-flow origin in Mediterranean basins. Geo-Mar. Lett. 1 (2), 77-83.

Strasser, M., Stegmann, S., Bussmann, F., Anselmetti, F.S., Rick, B., Kopf, A., 2007. Quantifying subaqueous slope stability during seismic shaking: Lake Lucerne as model for ocean margins. Mar. Geol. 240, 77-97.

Strasser, M., Moneke, K., Schnellmann, M., Anselmetti, F.S., 2013. Lake sediments as natural seismographs: a compiled record of Late Quaternary earthquakes in Centra Swit-zerland and its implication for Alpine deformation. Sedimentology 60, 319 341. http://dx.doi.org/10.1111/sed.12003.

Stuiver, M., Reimer, P.J., Reimer, R.W., 2005. CALIB 5.0 (WWW program and documentation)

Sumner, E.J., Siti, M.I., McNeill, L.C., Talling, P.J., Henstock, T.J., Wynn, R.B., Djajadihardja, Y.S., Permana, H., 2013. Can turbidites be used to reconstruct a paleoearthquake record for the central Sumatran margin? Geology 41, 763-766. http://dx.doi.org/10. $1130 / \mathrm{G} 34298.1$.

Talling, P.J., 2014. On the triggers, resulting flow types and frequencies of subaqueous sediment density flows in different settings. Mar. Geol. 352, 155-182.

Tappin, D.R., 2008. The 1908 Messina tsunami. Some comments on the source: earthquake, submarine landslide or a combination of both? Eos Trans. AGU Fall Meeting 53 (Supplementary 89) (Abstract S41D-07).

Tinti, S., Maramai, A., Graziani, L., 2004. The new catalogue of the Italian tsunamis. Nat. Hazards 33, 439-465.

Tinti, S., Armigliato, A., Zaniboni, F., Tonini, R., Pagnoni, G., Gallazzi, S., Manucci, A., Pontrelli, P., 2008. Quale sorgente per il maremoto del 28 Dicembre 1908 nello Stretto di Messina? Terremoto, frana sottomarina o entrambe? $27^{\circ}$ Convegno Nazionale, Gruppo Nazionale di Geofisica Della Terra Solida, Trieste, Italy, pp. 191-192

Tonini, R., Armigliato, A., Pagnoni, G., Zaniboni, F., Tinti, S., 2011. Tsunami hazard for the city of Catania, eastern Sicily, Italy, assessed by means of Worst-case Credible Tsuna-mi Scenario Analysis (WCTSA). Nat. Hazards Earth Syst. Sci. 11, 1217-1232. http://dx. doi.org/10.5194/nhess-11-1217-2011.

Tripsanas, E.K., Bryant, W.R., Phaneuf, B.A., 2004. Depositional processes of uniform mud deposits (unifites), Hedberg Basin, northwest Gulf of Mexico; new perspectives (prefacers) In: Sager, W.W., Bryant, W.R., Doyle, E.H. (Eds.), High-resolution studles of Continental Margin Geology and Geohazards. AAPG Bulletin 88/6, pp. 825-840.

Valensise, G., Pantosti, D., 1982. A 125-Kyr-long geological record of seismic source repeatability: the Messina Straits (southern Italy) and the 1908 earthquake (MS 71). Terra Nova 4, 472-483.

Van Daele, M., Versteeg, W., Pino, M., Urrutia, R., De Batist, M., 2013. Widespread deformation of basin-plain sediments in Aysén fjord (Chile) due to impact by earthquake-triggered, onshore-generated mass movements. Mar. Geol. 337, 67-79. http://dx.doi.org/10.1016/j.margeo.2013.01.006

Van Daele, M., Cnudde, V., Duyck, P., Pino, M., Urria, R., De Batist, M., 2014. Multidirectional, synchronously-triggered seismo-turbidites and debrites revealed by X-ray computed tomography (CT). Sedimentology 61 (4), 861-880. http:// dx.doi.org/10.1111/sed.12070. 